\title{
Nuclear export of the small ribosomal subunit requires the Ran-GTPase cycle and certain nucleoporins
}

\author{
Terence I. Moy and Pamela A. Silver ${ }^{1}$ \\ Department of Biological Chemistry and Molecular Pharmacology, Harvard Medical School and The Dana-Farber Cancer \\ Institute, Boston, Massachusetts 02115 USA
}

\begin{abstract}
After their assembly in the nucleolus, ribosomal subunits are exported from the nucleus to the cytoplasm. After export, the 20S rRNA in the small ribosomal subunit is cleaved to yield $18 \mathrm{~S}$ rRNA and the small 5' ITS1 fragment. The 5' ITS1 RNA is normally degraded by the cytoplasmic Xrn1 exonuclease, but in strains lacking XRN1, the 5' ITS1 fragment accumulates in the cytoplasm. Using the cytoplasmic localization of the $5^{\prime}$ ITS1 fragment as an indicator for the export of the small ribosomal subunit, we have identified genes that are required for ribosome export. Ribosome export is dependent on the Ran-GTPase as mutations in Ran or its regulators caused $5^{\prime}$ ITS1 to accumulate in the nucleoplasm. Mutations in the genes encoding the nucleoporin Nup82 and in the NES exporter Xpo1/Crm1 also caused the nucleoplasmic accumulation of $5^{\prime}$ ITS1. Mutants in a subset of nucleoporins and in the nuclear transport factors Srp1, Kap95, Pse1, Cse1, and Mtr10 accumulate the 5' ITS1 in the nucleolus and affect ribosome assembly. In contrast, we did not detect nuclear accumulation of $5^{\prime}$ ITS1 in 28 yeast strains that have mutations in other genes affecting nuclear trafficking.
\end{abstract}

[Key Words: Ribosome; nuclear export; in situ hybridization; rRNA processing]

Received May 13, 1999; revised version accepted June 23, 1999.

In the nucleolus, ribosomal RNA is transcribed, processed, and assembled with ribosomal proteins to produce ribosomal subunits. The small ribosomal subunit is composed of $\sim 32$ ribosomal proteins and an 18S rRNA. The large subunit is composed of $\sim 45$ ribosomal proteins and 5S, 5.8S, and 25S rRNAs (Warner 1971; Otaka and Kobata 1978; Vershoor et al. 1998). In the budding yeast Saccharomyces cerevisiae, RNA polymerase III transcribes the 5S rRNA, whereas RNA polymerase I transcribes the $35 \mathrm{~S}$ pre-rRNA. 18S, 5.8S, and 25S rRNAs are processed from the $35 \mathrm{~S}$ pre-rRNA through a number of endocytic and exocytic cleavages (Fig. 1; for review, see Venema and Tollervey 1995). Ribosomal proteins are translated in the cytoplasm, imported into the nucleus, and assembled with the rRNA while the rRNA is being processed. At least 40 ribosomes must be made every second in a yeast cell with a 90-min generation time (Tollervey et al. 1991). On average, this represents the nuclear import of 3100 ribosomal proteins every second and the export of 80 ribosomal subunits out of the nucleus every second. Thus, a significant fraction of nuclear trafficking is used in the production of ribosomes.

Ribosomal subunit export has been studied in vivo in Xenopus oocyte nuclei microinjected with ribosomal

${ }^{1}$ Corresponding author.

E-MAIL psilver@fas.harvard.edu; FAX (617) 632-5103. subunits and in vitro using isolated Tetrahymena nuclei. In these experiments, ribosomal subunit export has been shown to be an active process that is temperature and energy dependent (Giese and Wunderlich 1983; KhannaGupta and Ware 1989; Bataillé et al. 1990; Pokrywka and Goldfarb 1995). Ribosome transport is unidirectional in that cytoplasmic ribosomes do not enter the nucleus (Bataillé et al. 1990). Ribosomal subunit export is saturable, but at saturating levels of ribosomal subunits, export of tRNA is not affected (Bataillé et al. 1990; Pokrywka and Goldfarb 1995). This suggests that ribosomal subunit export requires transport factors that specifically recognize ribosomes. Xenopus nuclei are capable of exporting ribosomes from yeast, Tetrahymena, and Escherichia coli (Bataillé et al. 1990; Pokrywka and Goldfarb 1995), indicating that the ribosome export machinery recognizes common structural motifs present on all ribosomes.

All macromolecular transport into or out of the nucleus occurs through the nuclear pore complex (NPC). In yeast, the nuclear pore is a 66-MD complex composed of proteins called nucleoporins (for review, see Davis 1995; Fabre and Hurt 1997). Although smaller proteins may diffuse across the NPC, active transport probably accounts for most macromolecular movement between the nucleus and the cytoplasm. The best studied substrates for nuclear import are proteins containing positively charged nuclear localization signals (NLS). The 


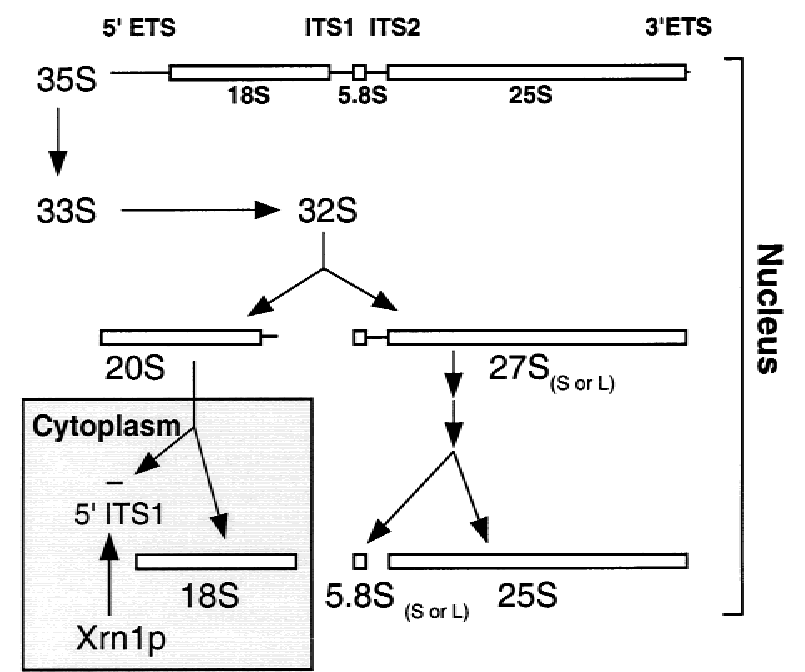

Figure 1. Diagram of rRNA processing in S. cerevisiae. 18S, $5.8 \mathrm{~S}$, and $25 \mathrm{~S}$ rRNAs are transcribed as a $35 \mathrm{~S}$ pre-rRNA in the nucleolus. The mature forms of the rRNAs are depicted as open bars and the external transcribed spacers (ETSs) and ITSs are depicted as lines. The 5' ETS undergoes endonucleolytic cleavages to yield the $33 \mathrm{~S}$ pre-rRNA and then the $32 \mathrm{~S}$ pre-rRNA. The ITS1 in the 32S pre-rRNA is cleaved to produce the 20S rRNA and the 27S rRNA. The 27S rRNA is processed through one of two pathways to produce the mature $5.8 \mathrm{~S}$ and $25 \mathrm{~S}$ rRNAs. The different pathways produce $5.8 \mathrm{~S}$ rRNAs with different lengths (long or short). The final maturation of the 20S rRNA occurs in the cytoplasm. In the cytoplasm, an endonucleolytic cleavage produces the mature 18S rRNA and a 209- to 210-base fragment, the $5^{\prime}$ ITS1. The $5^{\prime}$ ITS1 fragment is then degraded by the exonuclease XRN1 (for review, see Venema and Tollervey 1995).

NLS is recognized by a heterodimer composed of $\alpha$ and $\beta$ subunits and termed importin/karyopherin. The trimeric cargo/importin complex docks at the NPC, translocates through the pore, and is then disassembled (Adam and Adam 1994; Moore and Blobel 1994; Görlich et al. 1995). The binding of Ran-GTP to importin $\beta$ is believed to trigger the dissociation of the importin $\alpha / \beta /$ NLS protein complex. Ran-GTP is predicted to predominate in the nucleus and Ran-GDP in the cytoplasm, as the exchange factor for Ran (termed Rcc1 or Prp20 in yeast) is localized to the nucleus and the Ran-GTPaseactivating protein (termed Rnal) is localized to the cytoplasm (Hopper et al. 1980; Corbett et al. 1995; Görlich et al. 1996; Izaurralde et al. 1997). This gradient of RanGTP to Ran-GDP is believed to impart directionality to nuclear transport. According to a current model of nuclear trafficking, $\beta$ s functioning in import can bind their cargo in the presence of Ran-GDP but not RanGTP (Görlich 1998). Conversely, ßs functioning in export can only bind their cargo while bound to Ran-GTP. After export through the NPC, hydrolysis of Ran-GTP to produce Ran-GDP results in the disassembly of the $\beta$ and its cargo in the cytoplasm.

Yeast have at least 14 importin $\beta$ family members and each of these $\beta s$ is believed to be either a nuclear importer or exporter. Mutants have been generated in many of the corresponding genes and the transport of various cargoes analyzed in vivo (Koepp et al. 1996; Fornerod et al. 1997; Rout et al. 1997; Schlenstedt et al. 1997; Seedorf and Silver 1997; Stade et al. 1997). For example, XPO1/ $C R M 1$ encodes the export receptor for proteins with leucine-rich nuclear export sequences (NES). PSE1/KAP121 and PSE1/KAP123 have been implicated in the import of the ribosomal protein RPL25 and genetic analysis indicates that their functions are at least in part redundant. The import of ribosomal proteins in mammalian cells has also been shown to be a highly redundant process. Four different importin $\beta$ s have been found to be able to import independently three different ribosomal proteins (Jäkel and Görlich 1998).

In this paper, we present an assay to study the export of the small ribosomal subunit. By monitoring the export of the rRNA in the small ribosomal subunit, we have determined the roles of nuclear transport factors and nucleoporins in ribosome export. We show that we can distinguish between mutations that affect early ribosomal assembly versus those that affect the export of assembled small ribosomal subunits.

\section{Results}

Small ribosomal subunit export assay

To assay ribosomal subunit export, we have taken advantage of the unidirectional transport of rRNA out of the nucleus and the cytoplasmic maturation of the small ribosomal subunit in yeast. In $S$. cerevisiae, the $43 \mathrm{~S}$ preribosomal subunit is assembled in the nucleolus before export to the cytoplasm (Udem and Warner 1973). In the cytoplasm, the 20S rRNA in this 43S complex is cleaved by an endonuclease (Stevens et al. 1991). This cleavage produces the mature $18 \mathrm{~S}$ rRNA and a 209- to 210-base fragment, the 5' ITS1 (diagrammed in Fig. 1). The 5' ITS1 (internal transcribed spacer 1) fragment is then degraded by the 5'-3' exonuclease Xrn1 (Stevens et al. 1991). In strains lacking XRN1, the cleaved 5' ITS1 fragment accumulates in the cytoplasm. Thus, the cytoplasmic localization of the 5' ITS1 should reflect the export of the small ribosomal subunit.

We have developed an in situ hybridization assay to monitor the localization of the 5' ITS1 rRNA. In brief, a digoxigenin-labeled 5' ITS1 probe was generated and used to probe formaldehyde-fixed yeast cells (see Materials and Methods). In wild-type cells, a single discrete region of the nucleus hybridized with the probe (Fig. 2b). This region corresponds to the nucleolus as determined by costaining with an antibody against the nucleolar protein Nop1 (Fig. 2c,d). In yeast, the nucleolus is a crescent-shaped structure that occupies approximately onethird of the nucleus (Fig. 2c) and is physically separate from chromosomal DNA (Fig. 2a). The localization of 5' ITS1 to the nucleolus was expected because this is the site of rRNA transcription and ribosomal assembly. Only a weak signal for the 5' ITS1 can be seen in the cytoplasm.

Because the 5' ITS1 rRNA is degraded in the cyto- 
Figure 2. Localization of $5^{\prime}$ ITS1 RNA in wildtype (XRN1) and $\Delta x r n 1$ yeast cells. Chromosomal DNA was labeled with DAPI to identify the location of the nucleus. DAPI-stained cells are shown in blue $(a, e) .5^{\prime}$ ITS1 RNA was hybridized and labeled with a 200-bp probe and Texas Red-conjugated antibodies and is shown in red $(b, f)$. Immunofluorescence with antiNop1 was used to identfy the location of the nucleolus and is shown in green $(c, g)$. The DAPI, 5' ITS1, and Nop1 signals were overlayed in $d$ and $h$; colocalization of the $5^{\prime}$ ITS1 and Nop1 produces a yellow signal.

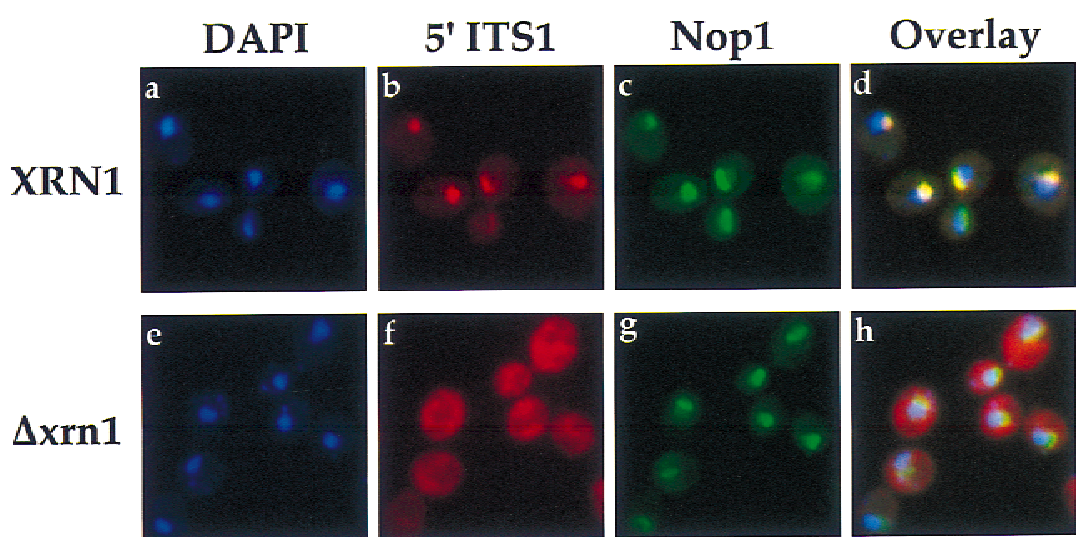

To further confirm the utility of the in situ assay, we analyzed the distribution of the 5' ITS1 in a number of mutant strain backgrounds. Strains lacking XRN1 are not temperature sensitive, and the distribution of $5^{\prime}$ ITS 1 rRNA remains cytoplasmic at $37^{\circ} \mathrm{C}$ (Fig. $3 \mathrm{~A}, \mathrm{~g}$ ) and at $15^{\circ} \mathrm{C}$ (data not shown). Therefore, we were able to disrupt $X R N 1$ in strains that have temperature-sensitive $\left(t s^{-}\right)$defects in factors known to affect ribosome assembly and observe the distribution of $5^{\prime}$ ITS1 at permissive and restrictive temperatures. A $t s^{-}$mutation that affects the assembly of the small ribosomal subunit will not be able to export the ribosomal subunit from the nucleus. Consequently, such a mutant should lose cytoplasmic 5' ITS1 signal when shifted to the restrictive temperatures.

somal subunit as one would predict.

Figure 3. Localization of 5' ITS1 and Nop1 in wild-type strains and rRNA processing mutants. Localization was determined as in Fig. 2. (A) XRN1 and $\Delta \mathrm{xrn} 1$ cells were grown at $25^{\circ} \mathrm{C}$ or shifted to $37^{\circ} \mathrm{C}$ for $1 \mathrm{hr}$. (B) mtr4-1 $\Delta x r n 1$ and fal1-1 $\Delta \mathrm{xrn} 1$ cells were grown at $25^{\circ} \mathrm{C}$ or shifted to $37^{\circ} \mathrm{C}$ for 1 or $4 \mathrm{hr}$, respectively.
A

XRN1 ${ }^{+}$

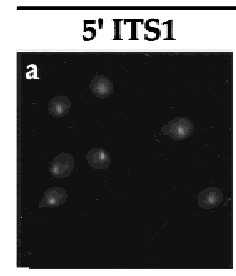

$25^{\circ} \mathrm{C}$
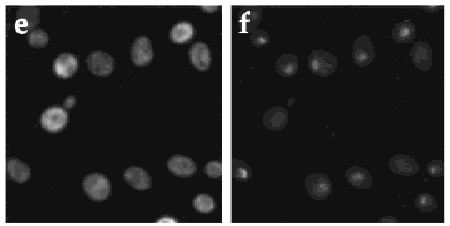

B

mtr4-1
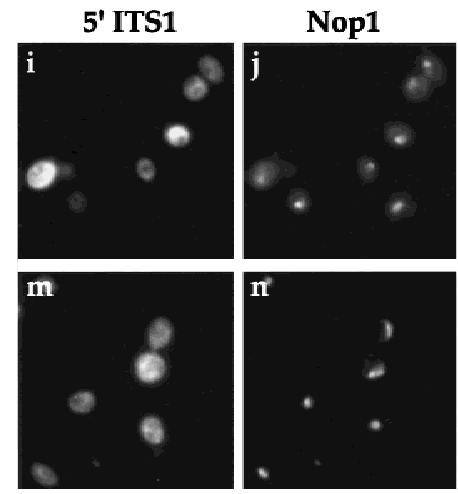

$37^{\circ} \mathrm{C}$
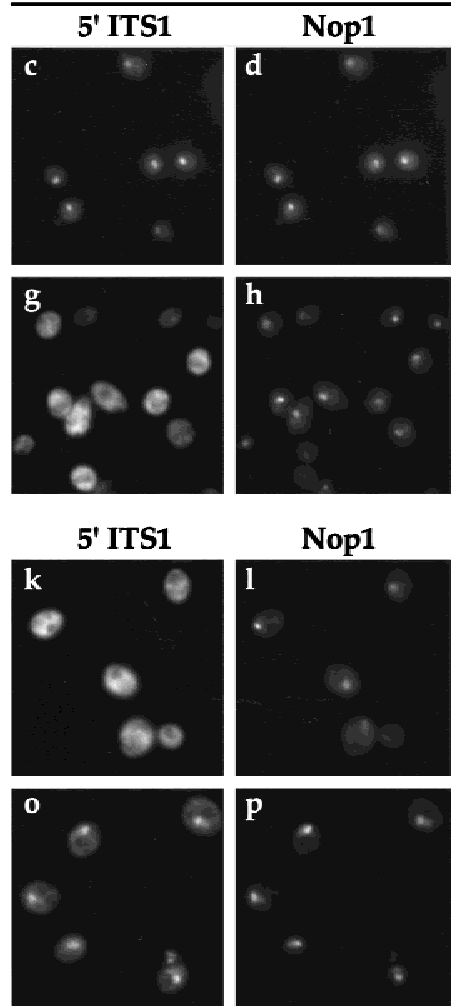
On the other hand, a conditional mutation that only affects the assembly of the large ribosomal subunit might not be expected to have impaired export of the small ribosomal subunit. Thus, the localization of $5^{\prime}$ ITS1 rRNA should not change in this type of mutant at restrictive temperatures.

Therefore, the localization of the 5' ITS1 rRNA was examined in mutants defective in large ribosomal subunit assembly. dob1-1 is reported to have defects in assembly of the large ribosomal subunit because $5.8 \mathrm{~S}$ rRNA is not processed efficiently from 7S rRNA /de la Cruz et al. 1998). mtr4-1 is another allele of DOB1, and this strain has a mRNA export defect at restrictive temperatures (Liang et al. 1996). dob1-1 $\Delta$ xrn1 and mtr4-1 $\Delta x r n 1$ strains were constructed by transforming dob1-1 or mtr4-1 cells with a PCR product that removes the $X R N 1$ coding region by homologous recombination. The 5 ' ITS1 fluorescent in situ hybridization assay was carried out with dob1-1 $\Delta x r n 1$ and mtr4-1 $\Delta x r n 1$ strains grown at permissive temperatures or shifted to restrictive temperatures. No difference in 5' ITS1 localization can be seen in shifted or unshifted cells (Fig. 3B, i,k; data not shown for dob1-1). However, defects in rRNA processing and mRNA export have been reported to occur under these conditions. This result demonstrates that localization of $5^{\prime}$ ITS 1 is not affected nonspecifically by temperature-sensitive mutations. Furthermore, this result indicates that export of the small ribosomal subunit is independent from the assembly of the large ribosomal subunit.

Next, we examined the distribution of the $5^{\prime}$ ITS1 rRNA in fal1-1 mutants, which are defective in the assembly of the small ribosomal subunit (Kressler et al. 1997). Fall is required for the maturation of the $18 \mathrm{~S}$ rRNA; depletion of Fall results in the inhibition of early rRNA cleavage events and the accumulation of an aberrant 23S rRNA (Kressler et al. 1997). Because fal1-1 strains, at the restrictive temperature, are blocked in rRNA processing at a step before ribosome subunit export, the $5^{\prime}$ ITS1 fragment is not expected to be transported to the cytoplasm. When 5' ITS1 was localized in fal1-1 $\Delta$ xrn1 strains shifted to the restrictive temperature, 5' ITS1 signal accumulated strongly in the nucleolus, whereas the cytoplasmic 5' ITS1 signal decreased significantly (Fig. 3B, m,o). This accumulation is dependent on the temperature sensitivity of fal1-1, as at permissive temperatures, the 5' ITS1 signal is distributed throughout the cytoplasm and the nucleolus (Fig. 3B, $\mathrm{m}, \mathrm{n})$. We have localized the 5' ITS1 rRNA in other mutants defective in the assembly of the small ribosomal subunit. XRN1 was disrupted in drs2-1, drs3-1, nop1-3, and nsr1 mutants (Kondo et al. 1992; Ripmaster et al. 1993; Tollervey et al. 1993), and these strains also accumulated 5' ITS1 in the nucleolus at restrictive temperatures (data not shown).

In sum, we have developed what we will term the small ribosomal subunit export assay. The distribution of 5' ITS1 rRNA is visualized by immunofluorescence microscopy in strains lacking XRN1; this acts as an indicator for the proper assembly and export of the small ribosomal subunit. Using this assay, we can examine conditional mutations that accumulate the $5^{\prime}$ ITS 1 in the nucleus at restrictive temperatures. This accumulation may be due to a direct inhibition of ribosomal subunit export, a defect in ribosome assembly, or an indirect result of the conditional mutation. The first two possibilities can be distinguished from each other by examining rRNA processing, which is tightly linked to ribosomal assembly. If ribosomal subunit export is specifically blocked, the $43 \mathrm{~S}$ preribosomal subunit should be trapped in the nucleus. Therefore, the 20S rRNA in this complex is expected to accumulate in the nucleus. If ribosomal assembly is blocked by defects in rRNA processing, aberrant forms of rRNA should accumulate as is the case for the fal1-1 and dob1-1 strains. If ribosomal assembly is blocked by the depletion of a ribosomal protein, rRNA processing is inhibited and unassembled rRNA and ribosomal proteins are quickly degraded (Gorenstein and Warner 1977; Moritz et al. 1990).

\section{Ribosome export requires the Ran-GTPase}

The small ribosomal subunit export assay was carried out on prp20-1, rna1-1, and yrb1-1 strains. Prp20 is the Ran-GDP exchange factor (RanGEF), Rnal is the RanGTPase-activating protein (RanGAP), and Yrb1 (yeast Ran binding protein 1) enhances RanGAP activity in the cytoplasm (Cheng et al. 1995; Corbett et al. 1995; Schlenstedt et al. 1995a). At the permissive temperature, the 5' ITS1 rRNA is distributed throughout prp20-1, rna1-1, and yrb1-1 cells (Fig. 4A, b,h,n). After a 1-hr shift to $37^{\circ} \mathrm{C}$, $>95 \%$ of prp20-1 and rna1-1 cells show accumulation of the $5^{\prime}$ ITS1 rRNA to an area that encompasses DAPI-stained chromosomal DNA (Fig. 4A e,k). This accumulation is confined within the nuclear envelope, because it is within the area delineated by nucleoporins and is not restricted to the nucleolus /data not shown). A majority of shifted yrb1-1 cells also accumulate the 5' ITS1 to the entire nucleus, but some yrb1-1 cells accumulate the $5^{\prime}$ ITS1 only to the nucleolus (Fig. 4A q). For prp20-1 and rna1-1 cells, the nuclear accumulation of $5^{\prime}$ ITS1 is detectable after a 10-min shift to $37^{\circ} \mathrm{C}$. The intensity of the cytoplasmic $5^{\prime}$ ITS 1 signal decreases after the temperature shift and after a 20-min shift, $\sim 75 \%$ of the cytoplasmic signal has disappeared (data not shown). Almost no detectable cytoplasmic signal is present after a $1-\mathrm{hr}$ shift to $37^{\circ} \mathrm{C}$ (Fig. $4 \mathrm{~A}$ e,k,q). The signal for the $5^{\prime}$ ITS 1 in the nucleus of shifted prp20-1 cells persists for $>4 \mathrm{hr}$. Overexpression of the Ran mutant gsp1 G21V, which is incapable of GTP hydrolysis (Schlenstedt et al. 1995b), also caused 5' ITS1 to accumulate in the nucleus (data not shown).

When prp20-1 cells are shifted to $37^{\circ} \mathrm{C}$, the nucleolus fragments; Nop1 is redistributed to 2 to 5 foci inside the nucleus (Aebi et al. 1990; Kadowaki et al. 1994). To determine whether the nuclear accumulation of $5^{\prime}$ ITS1 corresponded to the expanded distribution of the nucleolar protein Nop1, a three-dimensional image of 5' ITS1 and Nop1 localization was produced (Fig. 4B). 5' ITS1 is clustered around the nuclear periphery, whereas the cen- 


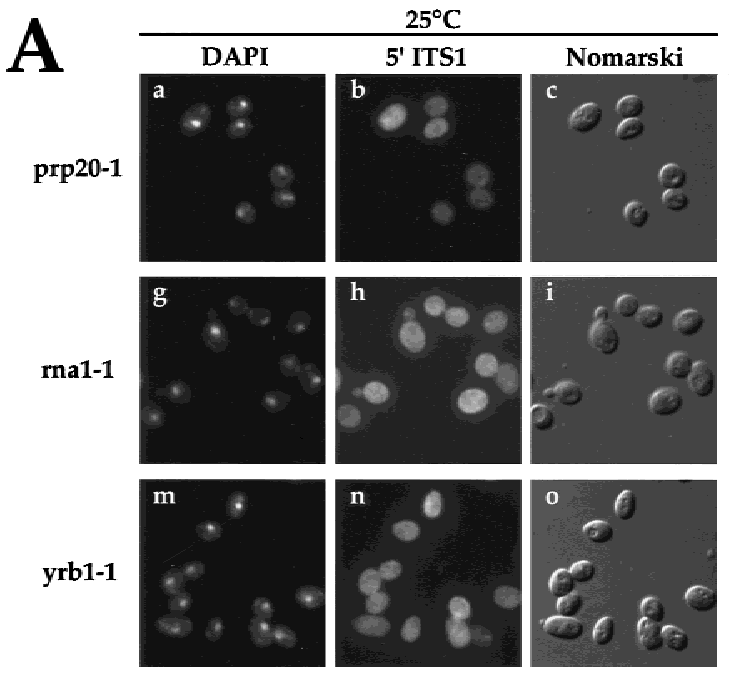

Figure 4. Localization of $5^{\prime}$ ITS1 in mutants affecting the Ran-GTPase cycle. (A) 5' ITS1 was localized in prp20-1 (RanGEF), rna1-1 (RanGAP), and yrb1-1 (RanBP1) cells grown at permissive $\left(25^{\circ} \mathrm{C}\right)$ or shifted to restrictive $\left(37^{\circ} \mathrm{C}\right)$ temperature for $1 \mathrm{hr}(b, e, h, k, n, q)$. The cells shown in this figure lack the Xrn 1 exonuclease. DAPI staining is used to identify the location of chromosomal DNA $(a, d, g, i, m, p)$ and Nomarski optics are used to visualize cell morphology $(c, f, i, 1, o, r)$. $5^{\prime}$ ITS1 localization to the entire nucleus of yrb1-1 cells (arrows) and to the nucleolus (arrowheads) is indicated in $q .(B)$ Localization of $5^{\prime}$

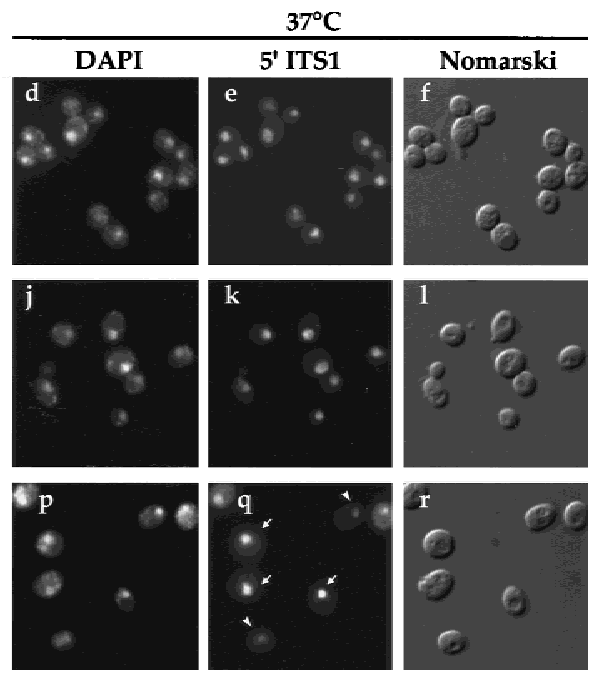

ITS1 and Nop1 in prp20-1 $\Delta x r n 1$ cells shifted to $37^{\circ} \mathrm{C}$. The images were deconvolved and the three dimensional reconstructions were projected onto two dimensions. 5' ITS1 signal is shown in red $(a)$ and Nop1 signal is shown in green $(b)$. The 5' ITS1 and Nop1 signals were overlayed in three dimensions and are shown in $c$.

ter of the nucleus has decreased 5' ITS1 signal (Fig. 4B a). Foci stained with anti-Nop1 antibodies also have decreased 5' ITS1 signal (Fig. 4B b,c). This indicates that the expanded nuclear signal for $5^{\prime}$ ITS1 is not simply attributable to the expanded localization of a nucleolar protein.

To verify that the export of the small ribosomal subunit is defective, rRNA processing in prp20-1, rna1-1, and yrb1-1 strains was examined. Cells were pulse-labeled with $\left[{ }^{3} \mathrm{H}\right]$ methionine for $3 \mathrm{~min}$ and then chased with excess unlabeled methionine for up to $10 \mathrm{~min}$. In wild-type yeast cells (PRP20), 35S rRNA is quickly converted to $27 \mathrm{~S}$ and $20 \mathrm{~S}$ pre-rRNAs. After $3 \mathrm{~min}$ of chase, wild-type cells convert almost all of these precursor rRNAs to the mature $25 \mathrm{~S}$ and $18 \mathrm{~S}$ forms (Fig. 5A, diagrammed in Fig. 1). At permissive temperatures, prp20-1 can process rRNA normally, but at restrictive temperatures prp20-1 accumulates 20S rRNA (Fig. 5A). No significant conversion of 20S rRNA to $18 \mathrm{~S}$ rRNA occurs in shifted prp20-1 cells during $3 \mathrm{~min}$ of chase. In contrast, PRP20 (PSY580) cells, shifted to $37^{\circ} \mathrm{C}$, completely convert 20S rRNA to $18 \mathrm{~S}$ rRNA within this time period (Fig. $5 \mathrm{~A})$. We have found that rna1-1, when shifted to $37^{\circ} \mathrm{C}$ for 10 min, also accumulates $20 \mathrm{~S}$ rRNA (data not shown). yrb1-1 cells shifted to $37^{\circ} \mathrm{C}$ for 10 min have a delay in conversion of $20 \mathrm{~S}$ rRNA to $18 \mathrm{~S}$ rRNA, where no conver- sion is detectable after 3 min of chase, but after $10 \mathrm{~min}$ of chase, almost all of the 20S rRNA has been converted to $18 \mathrm{~S}$ rRNA (data not shown).

To determine whether the 20S rRNA in shifted prp20-1 cells is assembled into the small ribosomal complex, we used sucrose gradients to fractionate lysates from shifted, pulse-labeled PRP20 and prp20-1 cells. 60S and $40 \mathrm{~S}$ peaks representing the large and small ribosomal subunits were collected (Fig. 5B) and RNA purified from these fractions was separated on formaldehyde-agarose gels (Fig. 5C). As expected for wild-type cells, 18-20S rRNAs were purified from the 40 S fraction and 25-27S rRNAs were purified from the 60S fraction. In prp20-1 cells, 20S rRNA is present in the 40S fraction but not in the 60S fraction or in the soluble fraction that did not enter the gradient (Fig. 5C). These data indicate that the 20S rRNA is assembled into a preribosomal complex. In total, the blocked conversion of $20 \mathrm{~S}$ to $18 \mathrm{~S}$ rRNA and the rapid onset of nuclear accumulation of 5' ITS1 at restrictive temperatures suggest that the Ran-GTP cycle is involved directly in ribosome export.

\section{Ribosome export requires a subset of nucleoporins}

The small ribosomal subunit export assay was carried out on 17 strains containing mutations in genes encod- 

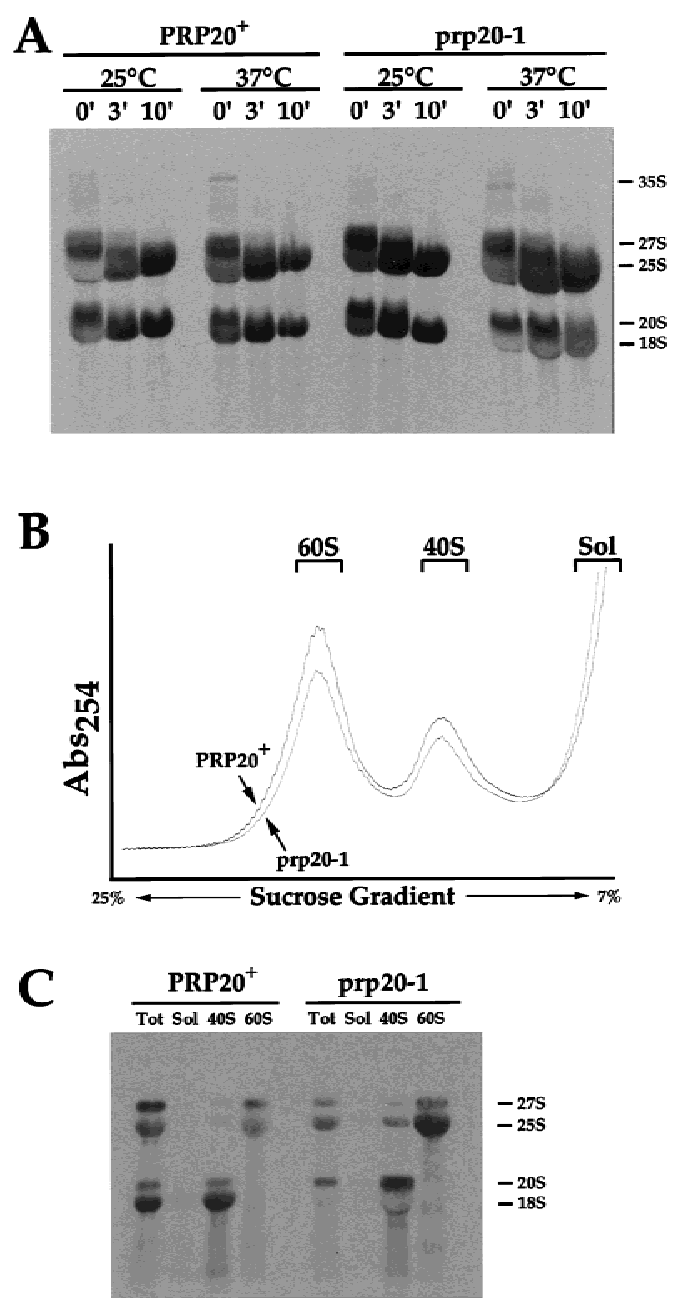

Figure 5. rRNA processing of wild-type (PRP20) and prp20-1 cells. (A) rRNA processing by pulse-chase analysis. PRP20 and prp20-1 cells were grown at permissive temperatures or shifted to $37^{\circ} \mathrm{C}$ for $10 \mathrm{~min}$. Cells were pulse-labeled and chased for 0,3 , or $10 \mathrm{~min}$. RNA was extracted and run on a formaldehydeagarose gel. The time points of the chase are labeled above each lane. $(B)$ Fractionation of ribosomal subunits by sucrose gradient centrifugation. $P R P 20$ and prp20-1 cells were shifted to $37^{\circ} \mathrm{C}$ for $10 \mathrm{~min} . A_{254} \mathrm{~nm}$ was used to detect the peaks of the $60 \mathrm{~S}$ and $40 \mathrm{~S}$ ribosomal subunits. Fractions for the $605,40 S$, and soluble proteins were collected. (C) rRNA present in the 60S, 40S, and soluble fractions were separated on formaldehyde-agarose gels. Total rRNA is also shown.

ing nucleoporins (Fabre and Hurt 1997). Eleven nucleoporin mutants accumulated 5' ITS1 in a similar pattern as strains defective in small ribosomal assembly; these mutants accumulated 5' ITS1 in the nucleolus at restrictive temperatures (Table 1). The intensity of nucleolar accumulation varied from mild to severe and three representative mutants are shown in Figure 6A. nup84- (Fig. 6A e-h), nic96-1, nsp1, nup120/rat2-2, rat3-1/nup133 (Fig. 6A i-1), and nup49-313 accumulate 5' ITS1 in the nucleolus only at $37^{\circ} \mathrm{C}$, whereas nup 1-8 and nup 116-5 show accumulation at $25^{\circ} \mathrm{C}$ and $37^{\circ} \mathrm{C}$ (not shown). Strains lacking nup2, nup100, or nup170 are not tem- perature sensitive and do not have detectable growth defects at any condition tested (Wente et al. 1992; Loeb et al. 1993; Aitchison et al. 1995). Yet nup2-4 (Fig. 6A a-d), snup100, and nup170-1 (not shown) mutants have a mild accumulation of $5^{\prime}$ ITS 1 in their nucleolus after growth at $37^{\circ} \mathrm{C}$ for $3 \mathrm{hr}$. To rule out the possibility that the nucleolar accumulation in these strains was attributable to a stress response, we localized 5' ITS1 in $\Delta x r n 1$ cells subjected to heat shock conditions. No changes in 5' ITS1 localization were observed under these conditions (data not shown).

We have found that both nup2-4 and nup170-1 strains have defects in rRNA processing. In pulse-chase experiments, nup2-4 (Fig. 7A) and nup170-1 (not shown) have a delay in processing of $35 \mathrm{~S}$ rRNA. More $35 \mathrm{~S}$ rRNA is detectable in nup2-4 cells during the pulse-labeling and after 3 min of chase than in $N^{2} P^{+}$cells (PSY580; Fig. 7). The nucleoporin mutant nup49-313 also accumulates higher molecular weight forms of rRNA and an aberrant 23S rRNA in pulse-chase experiments (Hurt et al. 1999). The slowed processing of high molecular weight rRNAs presumably occurs in the nucleolus and may be what is detected by the small ribosomal subunit export assay.

No nuclear accumulation of $5^{\prime}$ ITS1 was detected in gle2-/nup40 (Fig. 6B n,p), nup42/rip1-, nup157-2, rat71/nup159 (Fig. 6B r,t), or seh1- strains (data not shown). rat7-1/nup159 has a partial defect in mRNA export at permissive temperatures and a severe block in mRNA export after a 15 -min shift to $37^{\circ} \mathrm{C}$ (Gorsch et al. 1995). No accumulation of $5^{\prime}$ ITS1 was detected after shifting rat $7-1 /$ mup 159 cells to $37^{\circ} \mathrm{C}$ for up to $4 \mathrm{hr}$.

The small ribosomal subunit export assay was carried out on the nup $82 \Delta 108$ strain (Hurwitz and Blobel 1995). In contrast to the nucleoporin mutants that only accumulate $5^{\prime}$ ITS1 in the nucleolus, we found one-third of nup $82 \Delta 108$ cells accumulate the 5' ITS1 rRNA in their entire nucleus (Fig. 6C). In pulse-chase experiments, nup $82 \Delta 108$ cells have a delay in processing 35 S, 27S, and 20S rRNAs when shifted to restrictive temperatures (Fig. 7A).

\section{Ribosome export requires a subset of importin $\beta$ s}

The small ribosomal subunit export assay was carried out on $13 \beta$ mutants and the importin $\alpha$ mutant srp1-31 (Table 1). Pse1 is an importin $\beta$ that functions as an import receptor for ribosomal proteins (Rout et al. 1997; Schlenstedt et al. 1997; Jäkel and Görlich 1998). When pse 1-1 cells are shifted to restrictive temperatures, the $5^{\prime}$ ITS1 rRNA accumulates in the nucleolus. The intensity of the cytoplasmic 5' ITS1 signal in pse1-1 cells diminished by half after a 5-hr temperature shift (Fig. 8A f,h). In pulse-chase experiments, pse1-1 cells show a delay in rRNA processing; 35S, 27S, and 20S rRNAs are clearly visible after $3 \mathrm{~min}$ of chase, whereas in wild-type strains these precursor RNA forms are almost completely processed (Fig. 7A,B).

Importin $\beta /$ Kap95/Rs11 and importin $\alpha /$ Srp 1 are also involved in the import of ribosomal proteins (Jäkel and Görlich 1998) and Cse1/hCAS is the export receptor for 
Moy and Silver

Table 1. Classification of mutants based on the small ribosomal subunit export assay

\begin{tabular}{|c|c|c|c|c|}
\hline $\begin{array}{l}\text { Class } \boldsymbol{I}^{\mathrm{a}} \\
\text { Ran regulators }\end{array}$ & Nucleoporins ${ }^{\mathrm{b}}$ & Transport factors & $\beta s^{b}$ & Other \\
\hline $\begin{array}{l}\text { prp20-1 } \\
\text { rna1-1 } \\
\text { yrb1-1 }\end{array}$ & nup $82 \Delta 108$ & & xpo1-1 & \\
\hline $\begin{array}{l}\text { Class } \mathbf{I I}^{\mathbf{c}} \\
\text { Ribosomal } \\
\text { processing }\end{array}$ & Nucleoporins & Transport factors & $\beta s$ & Other \\
\hline $\begin{array}{l}\text { fal1-1 } \\
\text { nop1-3 } \\
\text { nsr } 1^{-} \\
\text {drs2-1 } \\
\text { drs3-1 }\end{array}$ & $\begin{array}{l}\text { nup1-8* } \\
\text { nup2-4 } \\
\text { nup49-313 } \\
\text { nup84- } \\
\text { Anup100 } \\
\text { nup116-5* } \\
\text { nup120/rat2-2 } \\
\text { nup133/rat3-1 } \\
\text { nup170-1 } \\
\text { nic96-1 } \\
\text { nsp1 }\end{array}$ & $\begin{array}{l}\text { gle1-4 } \\
\text { srp1-31 }\end{array}$ & $\begin{array}{l}\text { cse1-1* } \\
\text { mtr10-1 } \\
\text { pse1-1 } \\
\text { rsl1-4* }\end{array}$ & npl2-1 \\
\hline $\begin{array}{l}\text { Class } \text { III }^{\mathbf{d}} \\
\text { Ribosomal } \\
\text { processing }\end{array}$ & Nucleoporins & Transport factors & $\beta s$ & Other \\
\hline $\begin{array}{l}\text { dob1-1/mtr4-1 } \\
\text { drs1-1 } \\
\text { rat1-1 }\end{array}$ & $\begin{array}{l}\text { nup40/gle2 } \\
\text { nup42/rip1- } \\
\text { nup157-2 } \\
\text { nup159/rat7-1 } \\
\text { seh1 }^{-}\end{array}$ & $\begin{array}{l}\text { mex67-5 } \\
\text { mtr2-1 } \\
\text { npl3-17,-27 } \\
\text { npl4-1 } \\
\text { rat8-1 }\end{array}$ & 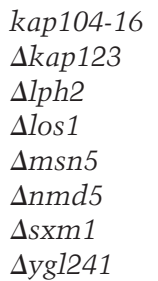 & $\begin{array}{c}\text { PSY580 (wild type) } \\
\text { Ahmt1 } \\
\text { hrp1-5 } \\
\text { mtr7-1 } \\
\text { rat5-1 } \\
\text { rat6-1 } \\
\text { rpb1-1 } \\
\Delta y d r 334\end{array}$ \\
\hline
\end{tabular}

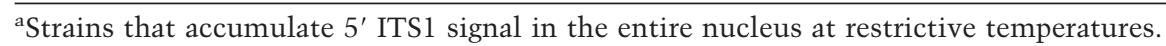

$\mathrm{b}\left({ }^{\star}\right)$ Strain also accumulates at permissive temperatures.

'Strains that accumulate 5' ITS1 signal in the nucleolus at restrictive temperatures.

d'Strains that do not accumulate 5' ITS1 signal in the nucleus.

importin $\alpha /$ Srp1 (Kutay et al. 1997; Hood and Silver 1998). srp1-31, rsl1-4, and cse1-1 strains accumulate the $5^{\prime}$ ITS1 in the nucleolus at restrictive temperatures (Fig. $8 \mathrm{~A}$ a-d; data not shown). Using pulse-chase analysis, we have found that cse1-1 and rsl1-4 cells have defects in rRNA processing (data not shown). In cse1-1 and rsl1-4 cells, the $35 \mathrm{~S}$ and $32 \mathrm{~S}$ forms of rRNA accumulate during the pulse-labeling, whereas in wild-type strains these high molecular weight RNAs are barely detectable. The defects in rRNA processing and the accumulation of 5' ITS1 in the nucleolus of these strains suggest that ribosomal assembly is inhibited.

Mtr10 is an importin $\beta$ that acts as an import receptor for the heterogenous nuclear ribonucleoprotein (hnRNP) Npl3p (Pemberton et al. 1997; Senger et al. 1998). mtr10-1 cells have a mRNA export defect and a defect in rRNA processing (Kadowaki et al. 1994). mtr10-1 cells weakly accumulate 5' ITS1 in the nucleolus at restrictive temperatures (Fig. 8A i-1). In contrast, a mutation in NPL3 does not cause $5^{\prime}$ ITS1 to accumulate in the nucleolus, although this mutation causes an mRNA export defect (Table 1; data not shown).
No accumulation of $5^{\prime}$ ITS1 was detected for $\Delta$ los 1 ,

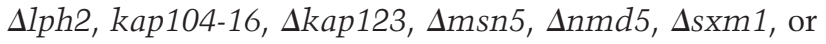
$\Delta$ ygl241 strains (Hurt et al. 1987; Aitchison et al. 1996; Seedorf and Silver 1997; Ferrigno et al. 1998; Fig 8B; data not shown). Of these eight $\beta$ mutants, only the kap10416 strain is temperature sensitive for growth, whereas the $\Delta$ los 1 strain is defective in tRNA export at restrictive temperatures (Aitchison et al. 1996, Sarkar and Hopper 1998). The los1-1 strain was reported to have normal rRNA processing (Hopper et al. 1980). The kap104-16 strain has a slight delay in rRNA processing at restrictive temperatures compared to wild-type (PSY580) cells (Fig. 7B). Although Kap123 has been implicated in ribosomal protein import, the 5' ITS1 did not accumulate in the nucleus of $\Delta$ kap123 cells (Rout et al. 1997, Schlenstedt et al. 1997; data not shown).

The small ribosomal subunit export assay was carried out with xpo1-1 cells and no accumulation of $5^{\prime}$ ITS1 could be detected at permissive temperatures (Fig. 8C $\mathrm{u}, \mathrm{v})$ or after a $1-\mathrm{hr}$ shift to $37^{\circ} \mathrm{C}$. After a 2 -hr shift to $37^{\circ} \mathrm{C}, 70 \%$ of xpo1-1 cells accumulated the $5^{\prime}$ ITS 1 rRNA in their entire nucleus. After a $4-\mathrm{hr}$ shift, $>95 \%$ of 
$\mathbf{A}$

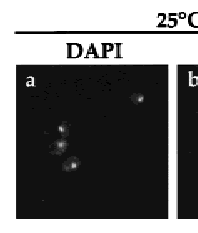

$25^{\circ} \mathrm{C}$
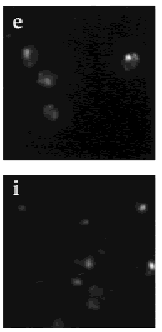

B

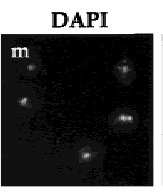
gle2/nup40

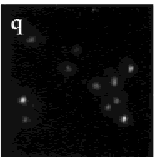

DAPI

C

nup82\108

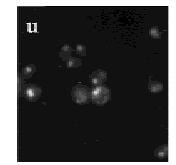

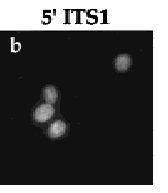
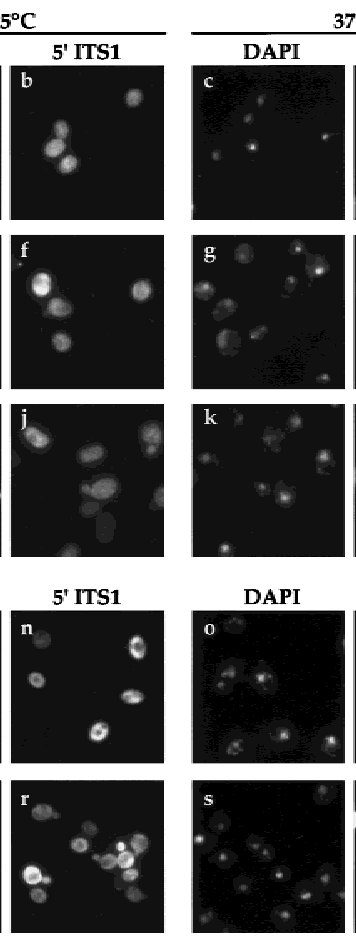

5' ITS1

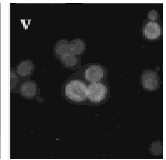

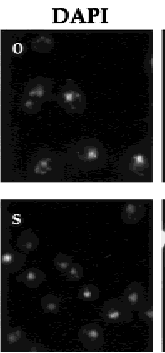

DAPI

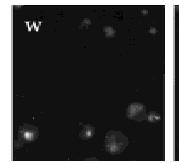

$37^{\circ} \mathrm{C}$
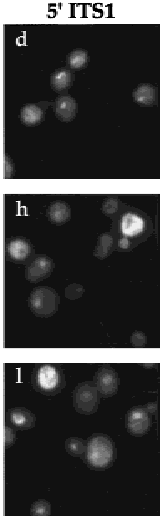

5' ITS1
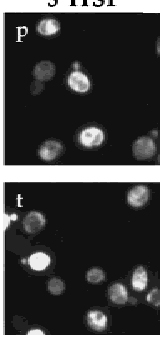

5' ITS1

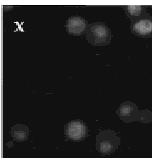

Figure 6. Localization of $5^{\prime}$ ITS1 in nucleoporin mutants. DAPI staining is shown in $a, c, e, g, i, k, m, O, q, s, u, W$ and $5^{\prime}$ ITS1 localization is shown in $b, d, f, h, j, 1, n, p, r, t, V, x$. (A) Nucleoporin mutants that acccumulate $5^{\prime}$ ITS 1 in the nucleolus at restrictive temperatures. nup2-4 $\Delta x r n 1$, nup $84^{-} \Delta x r n 1$, and rat3-1/nup120 $\Delta x r n 1$ cells were grown at permissive temperatures or shifted to $37^{\circ} \mathrm{C}$ for $3 \mathrm{hr}, 3 \mathrm{hr}$, or $1 \mathrm{hr}$, respectively. (B) Nucleoporin mutants that do not accumulate the $5^{\prime}$ ITS1 in the nucleus. gle2/ nup $40 \Delta x r n 1$ and rat $7 /$ nup $159 \Delta x r n 1$ cells were grown at $25^{\circ} \mathrm{C}$ or shifted to $37^{\circ} \mathrm{C}$ for $1 \mathrm{hr}$. (C) $5^{\prime}$ ITS 1 localization in nup $82 \Delta 108$ $\Delta x r n$ cells grown at $25^{\circ} \mathrm{C}$ or shifted to $37^{\circ} \mathrm{C}$ for $4 \mathrm{hr}$. About a third of nup $82 \Delta 108 \Delta x r n 1$ cells accumulate the $5^{\prime}$ ITS1 in their entire nucleus.

xpo1-1 cells accumulated the 5' ITS1 rRNA in the nucleoplasm (Fig. 8C w, $\mathrm{x}$ ). rRNA processing was analyzed for xpo1-1 cells shifted to $37^{\circ} \mathrm{C}$ for $1 \mathrm{hr}$ or for $4 \mathrm{hr}$ (Fig. 7B). In xpo1-1 cells shifted for $1 \mathrm{hr}$, the conversion of $20 \mathrm{~S}$ rRNA to 18S rRNA appears blocked, whereas the conversion of $27 \mathrm{~S}$ rRNA to $25 \mathrm{~S}$ rRNA is delayed. After xpo1-1 cells were shifted for $4 \mathrm{hr}$, the severity of the rRNA processing defects diminished; $18 \mathrm{~S}$ and $25 \mathrm{~S}$ rRNAs were processed more quickly into their mature forms. This adaptation to $37^{\circ} \mathrm{C}$ could indicate that xpo1-1 is not involved directly in ribosome export or it could indicate that cells have redundant factors involved in ribosome export.

We wanted to reconcile the differences in the timing of the rRNA processing defects of xpo1-1 and the onset of 5' ITS1 accumulation in xpo1-1 $\Delta x r n 1$. Detecting the

nuclear accumulation of $5^{\prime}$ ITS 1 in the small ribosomal subunit export assay requires the degradation of cytoplasmic 5' ITS1. A decreased rate of ribosome export may not be detectable with this assay if the export rate exceeds the rate of cytoplasmic 5' ITS1 degradation by RNases other than XRN1. Therefore, we used an alternative approach to detect defects in ribosome export; the $5^{\prime}$ ITS1 was localized in strains possessing functional XRN1. At permissive temperatures, 5' ITS1 localizes to the nucleolus (see Fig. 2b), but if ribosome export is blocked at the restrictive temperature, the 5' ITS1 signal should expand to occupy the entire nucleoplasm. This is the case for prp20-1 XRN1 cells as 5' ITS1 accumulates in the entire nucleus after a 5 -min shift to $37^{\circ} \mathrm{C}$ (Fig. 9c,d). No difference in $5^{\prime}$ ITS1 localization was detected in rat3-1, srp1-31, fal1-1, mtr10-1, rsl1-4, or wild-type strains at either permissive or restrictive temperatures; 5' ITS1 was localized to the nucleolus (Fig. 9a,b; data not shown). In xpo1-1 XRN1+ cells grown at permissive temperatures, most of the $5^{\prime}$ ITS1 signal is localized to the nucleolus. A small amount of signal is detected throughout the rest of the nucleus (data not shown). After a 5-min shift to $37^{\circ} \mathrm{C}$, all of the xpo1-1 cells accumulate the 5' ITS1 signal throughout their entire nucleus (Fig. $9 \mathrm{e}, \mathrm{f})$. This result suggests that ribosome export is blocked in these cells.

\section{Discussion}

We have developed a new assay to measure the export of the small ribosomal subunit in yeast. By localizing the 5' ITS1 rRNA in strains lacking XRN1, we are able to detect defects in ribosome export and assembly. We present evidence that ribosome export is Ran dependent and is affected by mutations in NUP82 and XPO1/CRM1. We also present evidence that ribosome assembly is extremely sensitive to mutations affecting nuclear transport. We found 11 nucleoporin mutants and 6 transport factor mutants that appear to have defects in ribosome assembly.

The small ribosomal subunit export assay is a highly sensitive assay that allowed us to examine the export of endogenous, unmodified ribosomal subunits and identify yeast mutations that affect ribosome export. An advantage of the ribosome export assay is that the transport of rRNA is unidirectional; 20S rRNA is only transported out of the nucleus. A limitation of this export assay is it relies on the null mutation of the XRN1 exonuclease. Strains lacking XRN1 accumulate deadenylated, uncapped messages as a result of decreased degradation of certain messenger RNAs (Hsu and Stevens 1993). This decreased degradation of mRNA can affect microtubule function, DNA replication, telomere length, and karyogamy (Dykstra et al. 1991; Interthal et al. 1995; Liu et al. 1995). Nevertheless, we believe the use of the null $X R N 1$ mutation is valid as the action of Xrn1 to degrade the 5' ITS1 fragment occurs after the cytoplasmic maturation of the small ribosomal subunit; the null mutation of XRN1 should not interfere directly with ribosome biogenesis. Furthermore, we have shown that the accumu- 
Figure 7. rRNA processing of nucleoporin mutants and importin $\beta$ mutants by pulse-chase analysis. (A) Wildtype (PSY580), nup2-4, and nup82 108 strains were grown at permissive temperatures or shifted to $37^{\circ} \mathrm{C}$ for 3 , 3, or $4 \mathrm{hr}$, respectively. (B) kap104-16, pse1-1, and xpo1-1 strains were grown at permissive temperatures or shifted to $37^{\circ} \mathrm{C}$ for $3 \mathrm{hr}, 5 \mathrm{hr}$, or the times indicated.
A

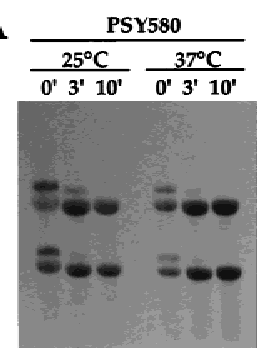

B

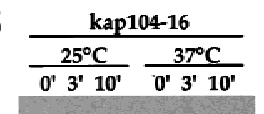

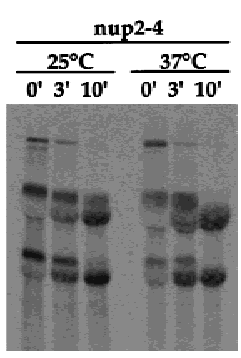

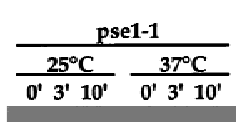

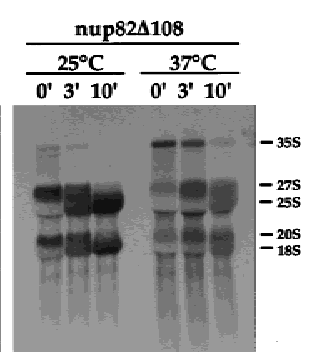

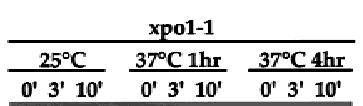

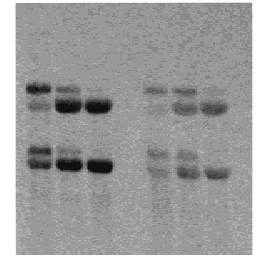
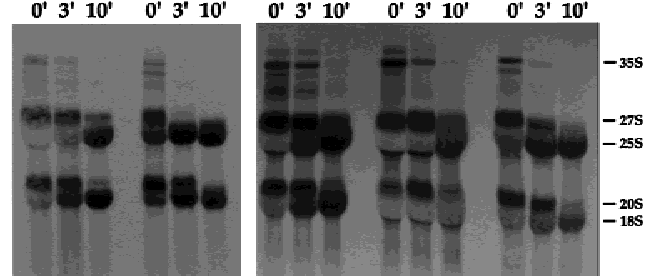

lation of the $5^{\prime}$ ITS1 to the entire nucleus can be detected in strains with a functional Xrn1 protein. However, for the most part, we used XRN1 null strains in this study because the loss of cytoplasmic 5' ITS1 signal was easier to detect than the enlargement of a nucleolar signal.

Evidence that ribosome export is regulated by Ran originated from a study on the rna1-1 mutation. rna1-1 cells have decreased entry of mRNA and rRNA to polysomes at restrictive temperatures (Petersen and Nierlich 1978). Petersen and Nierlich postulated that Rnal is involved in the export of both mRNA and rRNA out of the nucleus. In this report, we present more direct evidence that indicates Ran is involved in ribosome export. First, in temperature-sensitive mutants of Ran-GTPase regulators, the 5' ITS1 accumulates in the nucleus at restrictive temperatures. Second, the conversion of 20S rRNA to $18 \mathrm{~S}$ rRNA is blocked in these strains, although the 20S rRNA is assembled into a 40S preribosomal complex. Furthermore, we believe that localization of 5' ITS1 can detect the 20S rRNA in the small ribosomal subunit. If this is the case, the clustering of the $5^{\prime}$ ITS1 RNA around the nuclear periphery may represent small ribosomal subunits that are trapped at the nuclear envelope (Fig. 4B a).

Shifting prp20-1, rna1-1, or yrb1-1 to restrictive temperatures results in the block of NLS protein import, mRNA export, and tRNA export (Amberg et al. 1993; Schlenstedt et al. 1995b; Sarkar and Hopper 1998). Therefore, we anticipate that newly synthesized ribosomal proteins will not be able to enter the nucleus at restrictive temperatures. Ribosome assembly will eventually cease after a shift to restrictive temperatures. However, the ribosomal proteins already in the nucleus at the time of the temperature shift should, in principle, be assembled into ribosomal subunits. We believe that these assembled ribosomal subunits dissociate from the nucleolus but remain trapped in the nucleus at restrictive temperatures. In support of this interpretation, the addition of cycloheximide, which immediately inhibits protein synthesis, does not affect assembly of the small subunit until $20 \mathrm{~min}$ after cycloheximide addition (Warner 1971). A pool of ribosomal proteins may exist and the ribosomal proteins in this pool may be in the process of ribosomal assembly.

NUP82 is an essential nucleoporin that has been shown to bind to the nucleoporins NSP1 and NUP159 (Grandi et al. 1995; Belgareh et al. 1998; Hurwitz et al. 1998.) A carboxy-terminal deletion of 108 amino acids from Nup82 results in a temperature-sensitive strain that has a mRNA export defect but not a NLS protein import defect (Hurwitz and Blobel 1995). We have found that shifting nup $82 \Delta 108 \Delta \mathrm{xrn} 1$ strains to $37^{\circ} \mathrm{C}$ for $4 \mathrm{hr}$ or shifting nup $82 \Delta 108 X R N 1^{+}$strains to $37^{\circ} \mathrm{C}$ for $1 \mathrm{hr}$ results in the accumulation of $5^{\prime}$ ITS1 in the entire nucleoplasm of these strains (Fig 6C; data not shown). We do not know whether this nuclear accumulation of $5^{\prime}$ ITS1 is a direct effect of the nup $82 \Delta 108$ mutation, as this strain has a partial mRNA export block even at permissive temperatures. The block in rRNA processing of $35 \mathrm{~S}$, 27 , and 20S rRNAs in shifted nup824108 cells suggests that both ribosomal assembly and ribosome export are affected by mutations in NUP82.

Two nucleoporin mutations, nup2-4 and nup170-1, display accumulation of $5^{\prime}$ ITS 1 in the nucleolus at $37^{\circ} \mathrm{C}$. The corresponding nucleoporins are not essential in yeast and the null allele of each does not have detectable growth defects (Loeb et al. 1993; Aitchison et al. 1995). No transport defect has been reported for either nup2 or nup170 strains. The rate of ribosome assembly may be slowed in these mutants as they have a decreased rate of rRNA processing. Evidently the rate of ribosome biogenesis is not limiting to the growth rate of these mutants. We hypothesize that strains lacking NUP2 or NUP170 have mild defects in ribosomal protein import. The absence of these nucleoporins may affect the structure of the nuclear pore complex in a subtle manner such that nuclear trafficking is mildly affected.

We found five $\beta$ mutants that accumulate 5' ITS1 to 
A
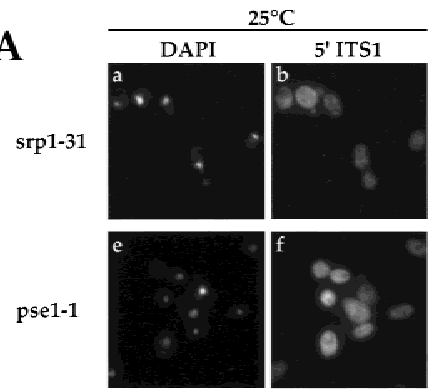

mtr10-1
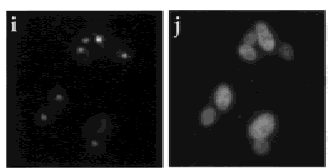

B

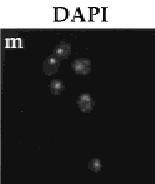

5' ITS1
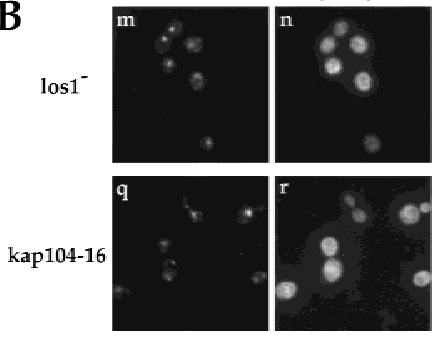

$\mathrm{C}$

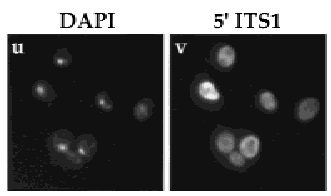

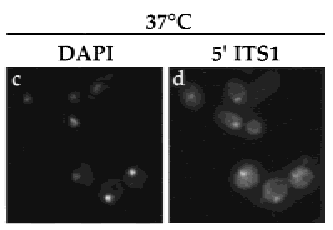
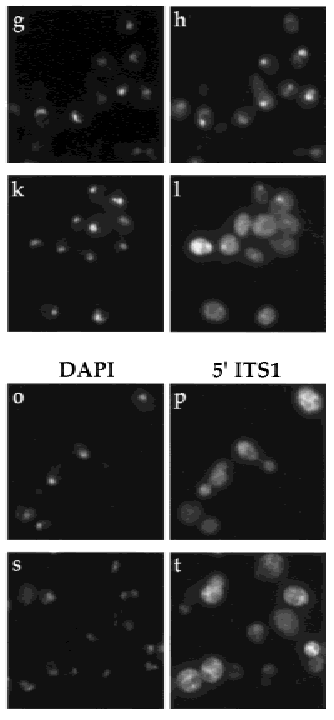

5' ITS1
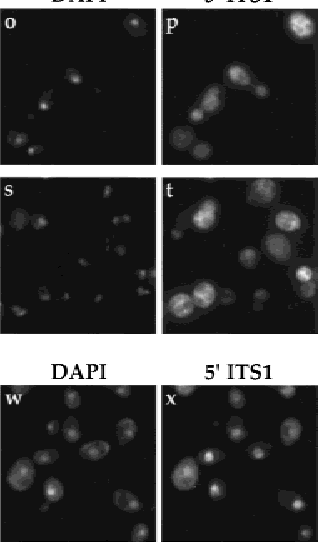

5' ITS1

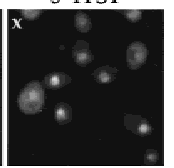

Figure 8. Localization of $5^{\prime}$ ITS 1 in nuclear transport factor mutants. DAPI staining is shown in $a, c, e, g, i, k, m, o, q, s, u, w$ and $5^{\prime}$ ITS1 localization is shown in $b, d, f, h, j, 1, n, p, r, t, v, x$. (A) Importin $\alpha$ mutant $\operatorname{srp} 1-31 \Delta x r n 1$ and importin $\beta$ mutants pse1-1 $\Delta x r n 1$ and mtr10-1 $\Delta x r n 1$ were grown at permissive temperatures or shifted to $37^{\circ} \mathrm{C}$ for 3,5 , or $3 \mathrm{hr}$, respectively. These strains accumulate $5^{\prime}$ ITS1 in the nucleolus at restrictive temperatures. (B) $\beta$ Mutants $\Delta \operatorname{los} 1 \Delta \mathrm{xrn} 1$ and kap104-16 $\Delta \mathrm{xrn} 1$ do not accumulate $5^{\prime}$ ITS1 in their nucleus when shifted to $37^{\circ} \mathrm{C}$ for $4 \mathrm{hr} .(C)$ xpo1-1 $\Delta \mathrm{xrn} 1$ cells accumulates $5^{\prime}$ ITS1 in their entire nucleus when shifted to $37^{\circ} \mathrm{C}$ for $4 \mathrm{hr}$.

the nucleolus at restrictive temperatures and have delays in rRNA processing. We suggest that these mutants are defective in ribosome assembly at restrictive temperatures. For the srp1, kap95, pse1, and cse1 mutants, ribosome assembly is expected to be inhibited because of defects in ribosomal protein import. However, in these mutants, rRNA processing appears delayed but not completely blocked at restrictive temperatures. Because ribosomal protein import is a highly redundant process that occurs through several importin $\beta$ receptors, the inhibition of one $\beta$ may not be sufficient to block ribosome assembly completely. The nucleolar accumulation of $5^{\prime}$ ITS1 in these mutants may represent rRNAs that are processed more slowly because of less efficient import of ribosomal proteins.

However, not all mutants with defects in nuclear trafficking have defects in ribosome export. We did not detect changes in $5^{\prime}$ ITS1 localization in 28 yeast strains

that have mutations in genes affecting nuclear transport. The activities of NPL3, MEX67, MTR2, and RAT8/DBP5 are required for mRNA export, but under conditions where mRNA export is blocked by these mutations, no accumulation of $5^{\prime}$ ITS1 to the nucleus was detectable (Kadowaki et al. 1994; Lee et al. 1996; Santos-Rosa et al. 1998; Snay-Hodge et al. 1998; Tseng et al. 1998). Los1 encodes a transport receptor for tRNA (Hellmuth et al. 1998), but no 5' ITS1 accumulation was detected in strains lacking Los1. This result supports the findings that rRNA processing in los1-1 cells is normal and that the tRNA export pathway is independent of the ribosome export pathway (Hopper et al. 1980; Pokrywka and Goldfarb 1995). Protein import or export is affected by the $\Delta m s n 5, \Delta n m d 5$, and $\Delta s \times m 1$ mutations (Rosenblum et al. 1997; Ferrigno et al. 1998; Kaffman et al. 1998), but these defects do not appear to affect ribosome export directly.

We have presented evidence that xpo1-1 cells are defective in the export of the small ribosomal subunit based on 5' ITS1 localization and on the defects in rRNA processing. However, the alleviation of the rRNA processing defect in xpo1-1 cells upon extended incubation at restrictive temperatures may indicate that XPO1/ CRM1 activity is not required directly for ribosome export. The xpo1-1 mutation mislocalizes Rnal to the nucleus at restrictive temperatures (Feng et al. 1999) and the severe phenotype of the xpo1-1 strain may be a result of a disrupted Ran-GTP gradient. We did not detect nuclear accumulation of 5' ITS1 in other alleles of crm1 that have an NES protein export defect (data not shown).
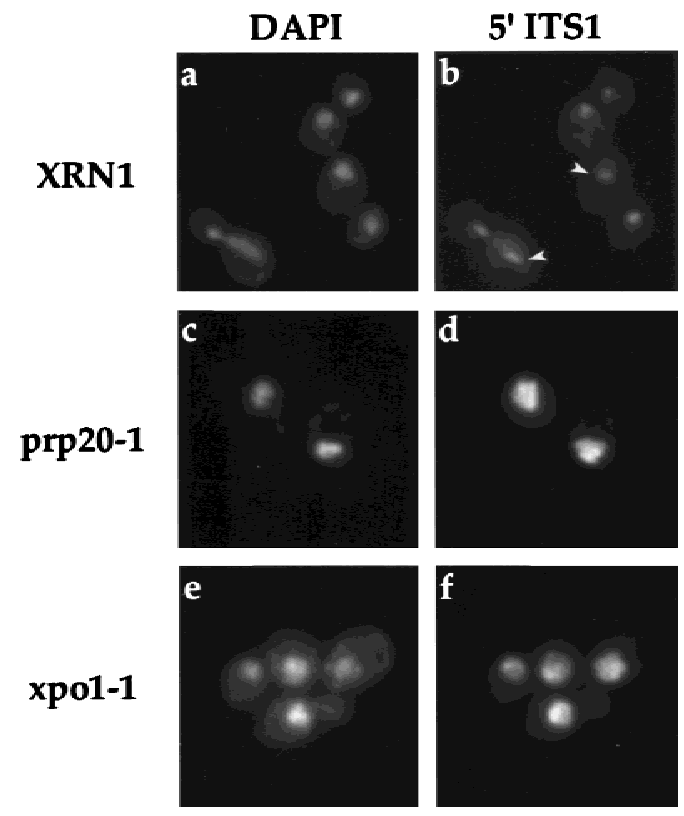

Figure 9. Localization of $5^{\prime}$ ITS1 in strains possessing functional XRN1 exonuclease. Wild-type (XRN1), prp20-1, and xpo1-1 cells were shifted to $37^{\circ} \mathrm{C}$ to induce mutant phenotypes. 5' ITS1 was localized to the nucleolus (arrowheads) of wild-type cells at restrictive temperatures. $5^{\prime}$ ITS was localized to the entire nucleus of prp20-1 and xpo1-1 cells, shifted to $37^{\circ} \mathrm{C}$. 
NES protein export activity does not appear to be required for ribosome export in higher eukaryotes as competition with excess NES protein does not result in decreased ribosome export (Fischer et al. 1995). An alternative interpretation for these data is that several transport pathways exist to export ribosomal subunits.

The export of the large ribosomal subunit was described in a recent report by Hurt et al. (1999). This report assayed ribosome export based on the localization of the large ribosomal protein RPL25 tagged with Green Fluorescent Protein (GFP). RPL25-GFP localizes to the cytoplasm at steady-state conditions in wild-type yeast cells. After prolonged starvation, the cytoplasmic signal disappears as ribosome synthesis decreases. However, when synthesis is allowed to resume after a shift back to permissive temperatures, appearance of nuclear ribosomal protein is observed in mutants where export is, in principle, blocked. Using this assay, the Ran-GTPase regulators were also found to be important for export of RPL25 as well as the nucleoporins Nup49, Nic96, and Nsp1.

Using the sequence of incubation at the nonpermissive temperature followed by a shift down to permissive temperatures, we localized 5' ITS1 in nsp1, nic96-1, and nup49-313 strains and found that the 5' ITS1 rRNA shifted from a nucleolar localization at restrictive temperatures to an accumulation in the entire nucleoplasm upon shifting back to permissive temperatures (data not shown). In contrast, fal1-1, mtr10-, nup84-, nup2-4, or pse1-1 strains do not accumulate the 5' ITS1 RNA in the entire nucleoplasm upon shifting down to permissive temperatures (data not shown). One interpretation of these data is that certain factors are required for both ribosome assembly and ribosome export. For the nsp1, nic96-1, and nup49-313 strains, the shift to restrictive temperatures appears to affect ribosome assembly before the defect in ribosome export can be detected.

In contrast to our results, Hurt et al. (1999) reported that RPL25 export is not affected by the xpo1-1, pse1-1, nup 84-, or nop1-7 mutations. These differences may be attributable to the nature of the two different assays. Alternatively, the requirements for small subunit export may differ from those for export of the large subunit. The RPL25-GFP-based assay requires ribosomal protein import into the nucleus so that accumulation can be detected. The 5' ITS1-based assay is able to identify factors required for ribosomal assembly, but the RPL25-GFP assay cannot. Because inhibition of ribosomal assembly has been shown to result in the degradation of unassembled ribosomal proteins, unassembled RPL25-GFP is not expected to accumulate in the nucleus.

As previously mentioned, in the RPL25-GFP assay, cells were first shifted to restrictive temperatures to induce the mutant phenotype and then shifted back to permissive temperatures for new synthesis and detection of RPL25. We interpret the requirement for the shift back to indicate that lag times exist between ribosomal protein import, ribosome assembly, and ribosome export. Nuclear accumulation of RPL25-GFP and 5' ITS1 would occur if the rate of ribosome assembly was greater than the rate of ribosome export. We have observed that a significant fraction of nic96-1 and nsp 1 cells accumulate the 5' ITS1 in their entire nucleus when ribosomal biogenesis is induced by transferring stationary phase cells to fresh media (Warner 1989; data not shown). Although we cannot quantify the rates of ribosome assembly and export based on these experiments, these observations are consistent with the idea that the rate of ribosome assembly can exceed the rate of export. Stimulation of ribosome biogenesis can result in a fivefold increase in ribosome production (Tushniski and Warner 1982; Powers and Walter 1999|, and it is conceivable that a yeast cell has a limited capacity for ribosome export. One limiting factor in ribosome export could be the large size of ribosomal subunits. A eukaryotic ribosome is $\sim 10$ $\mathrm{nm} \times 20 \mathrm{~nm} \times 15 \mathrm{~nm}$, whereas the diffusible channel of the NPC is $\sim 9 \mathrm{~nm}$ (Vershoor et al. 1998). Drastic conformation changes in the NPC or the ribosome must occur for ribosomal subunits to translocate through the pore.

In summary, we have described a new assay to monitor ribosome assembly and export. Using this assay, we conclude that nuclear trafficking is a crucial requirement for ribosome assembly. We also conclude that ribosome export is dependent on a subset of nucleoporins and is Ran dependent. Future studies will determine precisely how export is affected by these proteins and identify other factors that facilitate ribosome export.

\section{Materials and methods}

\section{Yeast strains}

Standard yeast methods and media were used (Adams et al. 1997). Yeast strains were generously given by the following laboratories: J.D. Aitchison (University of Alberta, Edmonton, Canada) (kap104), M. Clark (McGill University, Montreal, Canada) (prp20), C.N. Cole (Dartmouth Medical School, Hanover, NH) (rat1, rat2, rat3, rat5, rat6, rat7, rat8, rip1), J. de la Cruz (Universidad de Sevilla-CSIC, Sevilla, Spain) (dob1), G. Fink (Whitehead Institute for Biomedial Research, Cambridge, MA) (nup1, nup2), M. Fitzgerald-Hayes (University of Massachusetts, Amherst, MA) (cse1), A.K. Hopper (Pennsylvania State University College of Medicine, Hershey, PA) (rna1), E. Hurt (Biochemie-Zentrum Heidelberg, Heidelberg, Germany) (mex67, nop1, nup84, nic96, nsp1, seh1), M.E. Hurwitz (Rockefeller University, New York, NY) (nup82), M. Inouye (Robert Wood Johnson Medical School, Rutgers University, Piscataway, NJ) (nsr1), P. Linder (Universite de Geneva, Geneva, Switzerland) (fal1), M. Nomura (University of California, Irvine, CA) (srp1, rpa190), T.L. Ripmaster (Carnegie Mellon University, Pittsburgh, PA) (drs1, drs2, drs3), A. Stevens (Oak Ridge National Laboratory, TN) (YPH500, xrn1 $\Delta$ ), A. Tartakoff (Case Western Reserve University, Cleveland, OH) (mtr2, mtr4, mtr7, mtr10), K. Weis (University of California, Berkeley, CA) (xpo1), S. Wente (Washington University School of Medicine, St. Louis, MO) (gle1, gle2, nup49, nup100, nup116), F. Winston (Harvard Medical School, Boston, MA) (FY23= PSY580), R. Wozniak (University of Alberta, Edmonton, Canada) (nup157, nup170), and R. Young (Whitehead Institute for Biomedical Research, Cambridge, MA) (rpb1) (Table 2).

\section{Disruption of XRN1}

The entire coding sequence of $X R N 1$ was replaced by the URA3, 
Table 2. Yeast strains used in this study

\begin{tabular}{|c|c|c|}
\hline Strain & Genotype & Reference \\
\hline PSY580 & mata ura3-52 trp1 $\Delta 63$ leu2 $\Delta 1$ & Winston et al. (1995) \\
\hline PSY1750 & 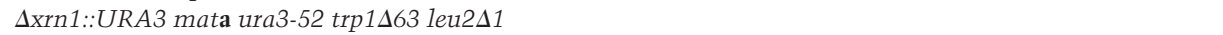 & this study \\
\hline PSY1190 & 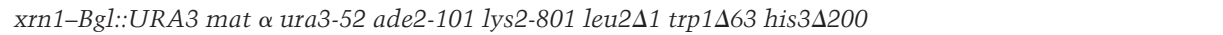 & Larimer and Stevens (1990) \\
\hline PSY1721 & 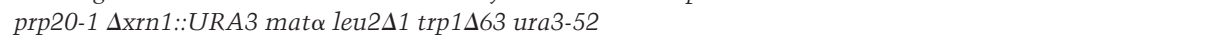 & Forrester et al. (1992) \\
\hline PSY1722 & 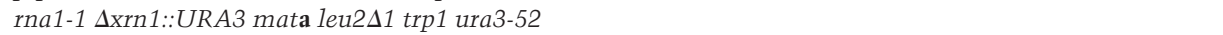 & Hartwell (1967) \\
\hline PSY1723 & Ayrb1::HIS3 $\Delta \mathrm{xrn1}::$ URA3 mata ade2 ade3 lys2 trp1 + pPS328-yrb1-1 (CEN LEU) & Schlenstedt et al. (1995a) \\
\hline PSY1724 & dob1-1 $\Delta$ xrn1::URA3 mata leu2-3,112 trp1-1 ura3-1 ade2-1 his3-11,15 & de la Cruz et al. (1998) \\
\hline PSY1725 & drs2-1 $\Delta x r n 1:: U R A 3$ ura3 trp1 & Ripmaster et al. (1993) \\
\hline PSY1726 & drs3-1 $\Delta x r n 1:: U R A 3$ ura3 trp1 his3 lys2 & Ripmaster et al. (1993) \\
\hline PSY1727 & Afal1::HIS3 $\triangle$ xrn1::URA3 mata ura3-1 ade2-1 his3-11,15 leu22-3,112 trp1-1 + pRS416-fal1-1 ts (LEU CEN) & Kressler et al. (1997) \\
\hline PSY1728 & URA::nop1-3 $\Delta$ xrn1::URA3 mata ade2 ade8 leu2 lys1 & Tollervey et al. (1993) \\
\hline PSY1729 & $\Delta n s r 1:: U R A 3 \quad \Delta x r n 1::$ LEU2 mata his3 leu2 ura3 trp1 ade8 can1 gal2 & Kondo et al. (1992) \\
\hline PSY1730 & 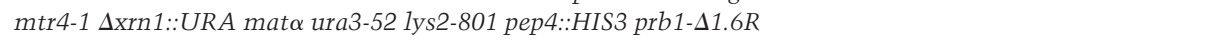 & Liang et al. (1996) \\
\hline PSY1731 & rat1-1 $\Delta \mathrm{xrn1::URA} \mathrm{mat \alpha}$ his $3 \Delta 200$ ura3-52 leu2 $\Delta 1$ & Amberg et al. (1992) \\
\hline PSY1732 & cse1-1 $\Delta$ xrn1::HIS3 mata ura3-52 his3-11,15 trp1 ade2 & Xiao et al. (1993) \\
\hline PSY1733 & gle1-4 $\Delta x r n 1:: U R A 3$ mata ade2-1 his3-11,15 leu2-3,112 ura3-1 & Murphy and Wente (1996) \\
\hline PSY1734 & kap104::URA::HIS $\triangle$ xrn1::URA3 mata ura3 leu2 lys2 trp1 + pRS314-kap104-16 (TRP CEN) & Aitchison et al. (1996) \\
\hline PSY1735 & 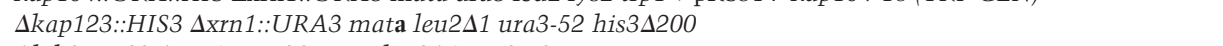 & Seedorf and Silver (1997) \\
\hline PSY1736 & 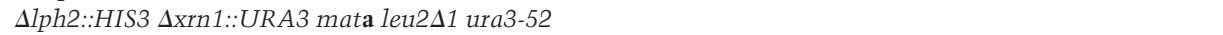 & \\
\hline PSY1737 & $\Delta \operatorname{los} 1:: H I S 3$ sxrn1::URA3 mata ade2 his3 leu2 trp1 ura3 & Hurt et al. (1987) \\
\hline PSY1738 & 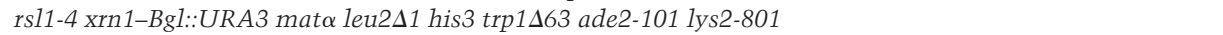 & Koepp et al. (1996) \\
\hline PSY1739 & 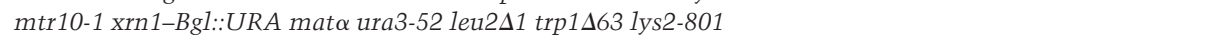 & Kadowaki et al. (1994) \\
\hline PSY1740 & $\Delta n m d 5$ Axrn1::URA3 mata leu2 ade trp1 & Ferrigno et al. (1998) \\
\hline PSY1741 & pse1-1 $\Delta$ xrn1::URA3 mata his3 trp1 leu2 & Seedorf and Silver (1997) \\
\hline PSY1742 & srp1-31 $\Delta x r n 1:: U R A 3$ mata ura3-52 leu2-3,112 trp1 his3 ade2 & Yano et al. (1994) \\
\hline PSY1743 & Asxm1::HIS3 $\Delta x r n 1::$ URA3 mata leu2 trp1 his3 lys2 & Seedorf and Silver (1997) \\
\hline PSY1744 & xpo1::LEU2 $\Delta x$ xrn1::URA3 mata ade2-1 ura3-1 trp1-1 can1-1 + pKW 457 (xpo1-1, HIS3) & Stade et al. (1997) \\
\hline PSY1745 & mex67::HIS2 $\Delta \times \operatorname{xrn} 1::$ URA3 mata ade7 his3 leu2 trp1 ura3 + pUN100-LEU2-mex67-5-GFP & Santos-Rosa et al. (1998) \\
\hline PSY1746 & 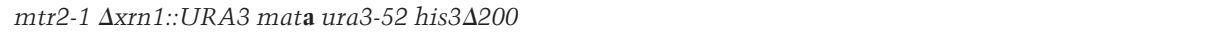 & Kadowaki et al. (1994) \\
\hline PSY1747 & np13-17 $\Delta$ xrn1::URA3 mata ade2-1 can1-100 his3 leu2-3 lys1-1 ura3-52 ade8 trpl-1 & Lee et al. (1996) \\
\hline PSY1748 & 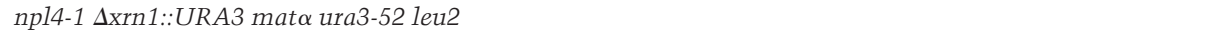 & De Horatius and Silver (1996) \\
\hline PSY1749 & rat8-1 $\Delta x r n 1:: U R A 3$ mata ura3 leu2 trp1 & Snay-Hodge et al. (1998) \\
\hline PSY1751 & $\Delta$ hmt1::HIS3 $\Delta x r n 1::$ URA3 mat $\alpha$ ade2 ade8 his3 leu2 lys1 ura3 & Henry and Silver (1996) \\
\hline PSY1752 & hrp1-5 $\Delta$ xrn1::URA3 mata ura3-1 trp1-1 ade2-1 leu2-3,112 his3-11,15 & Henry et al. (1996) \\
\hline PSY1753 & 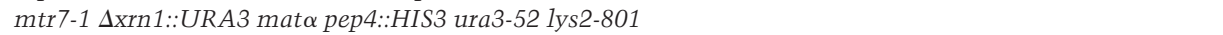 & Kadowaki et al. (1994) \\
\hline PSY1754 & 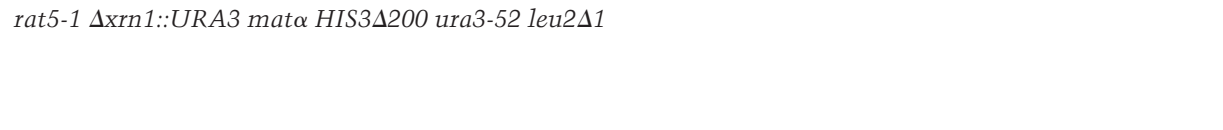 & $\begin{array}{l}\text { C.N. Cole } \\
\text { (Dartmouth Medical } \\
\text { School, } \\
\text { Hanover, NH) }\end{array}$ \\
\hline PSY1755 & 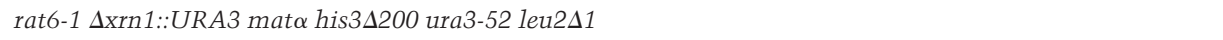 & C.N. Cole \\
\hline PSY1756 & 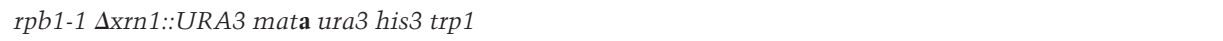 & Nonet et al. (1987) \\
\hline PSY1757 & np12-1 $\Delta x r n 1:: U R A 3$ mata ade leu2 trp1 ura3 & \\
\hline PSY1758 & 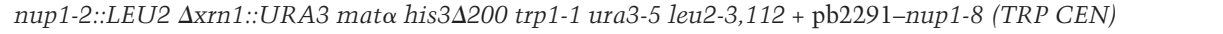 & Loeb et al. (1993) \\
\hline PSY1759 & 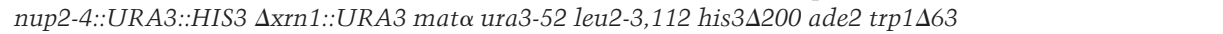 & Loeb et al. (1993) \\
\hline PSY1760 & gle2-1 $\Delta x r n 1:: U R A 3$ mat $\alpha$ ade2-1 ura3-1 his3 leu2 trp1 can1 & Murphy et al. (1996) \\
\hline PSY1761 & 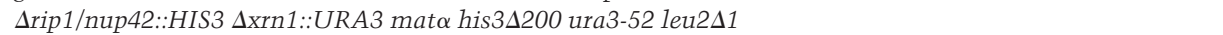 & Saavedra et al. (1997) \\
\hline PSY1762 & TRP1::nup49 $\triangle$ xrn1::URA3 mata ade2 ade3 his3 leu2 ura3 + pUN100::LEU2-nup49-313 & Hurt et al. (1999) \\
\hline PSY1763 & nup82::HIS3 $\Delta \times \mathrm{xrn1}::$ URA3 mata his3-4200 leu2-3,112 lys2-801 trp1-1 ura3-52 + nup82 $\Delta 108$ (LEU CEN) & Hurwitz and Blobel (1995) \\
\hline PSY1764 & nup84::HIS3 $\Delta \times \mathrm{xrn1}::$ URA3 ade2 mata leu2 ura3 trp1 & Siniossoglou et al. (1996) \\
\hline PSY1765 & Anup100-3::TRP1 $\Delta$ xrn1::URA3 mata ade2 his3 leu2 trp1 ura3 & Wente et al. (1992) \\
\hline PSY1766 & Anup116-5::HIS3 $\Delta \mathrm{x}$ rn1::URA3 mata his3 leu2 trp1 ura3 & Wente et al. (1992) \\
\hline PSY1767 & 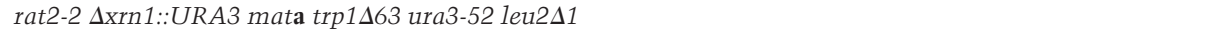 & Heath et al. (1995) \\
\hline PSY1768 & rat3-1 $\Delta x r n 1:: U R A 3$ mata leu2 $2 \Delta 1$ ura3-52 trp1 163 & Li et al. (1995) \\
\hline PSY1769 & nup157-2::URA $\Delta$ xrn1::URA3 mata ura3-52 his34200 trp1-1 leu2-3,112 lys2-801 & Aitchison et al. (1995) \\
\hline PSY1770 & rat7-1 $\Delta \times \mathrm{xrn} 1::$ URA3 mata his3 ura3 leu2 & Gorsch et al. (1995) \\
\hline PSY1771 & nup170-1::HIS3 $\triangle$ xrn1::URA3 ade2-1 ura3-1 his3-11,15 trp1-1 leu2-3,112 can1-100 & Aitchison et al. (1995) \\
\hline PSY1772 & nic96::HIS3 $\triangle$ xrn1::URA3 mata ade2 ura3 trp1 leu2 + pUN100-nic96-1 (CEN LEU2) & Zabel et al. (1996) \\
\hline PSY1773 & 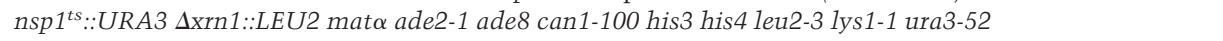 & Nehrbass et al. (1990) \\
\hline PSY1774 & 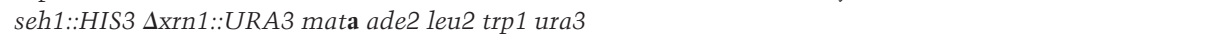 & Siniossoglou et al. (1996) \\
\hline PSY1778 & 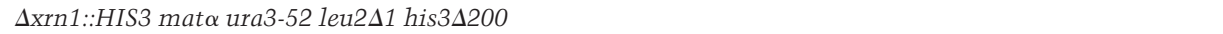 & this study \\
\hline PSY1782 & ayg1241::HIS3 $\Delta x$ xrn1::URA3 mata ade2 leu2 lys2 trp1 ura3 & \\
\hline PSY1805 & sydr334::HIS3 $\Delta x r n 1:: U R A 3$ mata leu2 trp1 ura3 & \\
\hline PSY1806 & Amsn5::HIS3 $\triangle$ xrn1::LEU2 np13-27 mata ura3 trp1 ade2 lys2 & \\
\hline
\end{tabular}

LEU2, or HIS3 genes. PCR was used to amplify URA3, LEU2, or HIS3 genes flanked with $50 \mathrm{bp}$ at each end corresponding to the XRN1 5' UTR and 3' UTR. This PCR product was transformed into auxotrophic yeast strains and $\mathrm{URA}^{+}, \mathrm{LEU}^{+}$, or $\mathrm{HIS}^{+}$colonies were grown on selective media. Disruption of XRN1 was confirmed by PCR. Alternatively, the $\Delta x r n 1$ mutation was in- 
troduced into different yeast strains by mating, sporulating, and dissecting tetrads (Adams et al. 1997).

\section{Localization of 5' ITS1 rRNA}

5' ITS1 rRNA was localized by fluorescence in situ hybridization as described (Amberg et al. 1992) with some modifications. The template for the 5' ITS1 probe was $200 \mathrm{bp}$ of rDNA amplified by PCR from yeast genomic DNA using the following primers: 5' -AATTTAATAATTTTGAAAATGGATTTT-3' and 5'-GAAACGGTTTTAATTGTCCTAT-3'. The digoxigenin-labeled 5' ITS1 probe was generated by PCR using this template DNA, the primers indicated, and digoxigenin-11-dUTP at a 1:4 ratio with dTTP. Yeast strains were grown to a density of $1 \times 10^{7}-4 \times 10^{7}$ and fixed with $4.4 \%$ formaldehyde for $90 \mathrm{~min}$. Samples were hybridized to $50 \mathrm{ng} / \mathrm{ml}$ digoxigenin-labeled $5^{\prime}$ ITS1 for $14 \mathrm{hr}$ at $37^{\circ} \mathrm{C}$.

\section{Colocalization of 5' ITS1 and Nop1}

For colocalization of 5' ITS1 rRNA with anti-Nop1 monoclonal antibodies, permeabilized cells affixed to a slide were blocked with $10 \mathrm{mg} / \mathrm{ml}$ BSA in $1 \times$ PBS. Anti-Nop1 antibodies were incubated with the cells for $4 \mathrm{hr}$ at $23^{\circ} \mathrm{C}$. After washing three times with $1 \times$ PBS, cells were treated with $3.7 \%$ formaldehyde in $1 \times$ PBS for $20 \mathrm{~min}$. Slides were then treated as described by Amberg et al. (1992) starting with the triethanolamine incubation. Immunofluorescence microscopy was performed as described (Ferrigno and Silver 1999; Seedorf et al. 1999). For Figure $4 \mathrm{~B}$, images were acquired and processed on a DeltaVision platform. Data were collected in 100-nm sections, subjected to five cycles of derivative deconvolution (Agard et al. 1989), and projected onto two dimensions for display.

\section{Pulse-chase analysis of $r R N A$ processing}

Cells were labeled with [methyl- $\left.{ }^{3} \mathrm{H}\right]$ methionine, which is incorporated into ribosomal RNA but not into other forms of RNA. Cells were grown to a density of $1 \times 10^{7}-2 \times 10^{7}$ cells $/ \mathrm{ml}$ in S.D. media lacking methionine $\left(\right.$ met $\left.^{-}\right)$at $25^{\circ} \mathrm{C}$. For temperature shifts $<1 \mathrm{hr}$, an equal volume of media prewarmed to $50^{\circ} \mathrm{C}$ was added to the culture to initiate the $37^{\circ} \mathrm{C}$ shift. Cells were collected and resuspended in met $^{-}$media at a density of $3 \times 10^{8}$ cells $/ \mathrm{ml}$ in a volume of $3 \mathrm{ml}$. [ ${ }^{3} \mathrm{H}$-methyl]methionine $(0.2 \mathrm{mCi})$ (specific activity, $>70 \mu \mathrm{Ci} / \mathrm{mmole}$; NEN) was added and cells were labeled for $3 \mathrm{~min}$. After $3 \mathrm{~min}, 1-\mathrm{ml}$ aliquots were added to $0.5 \mathrm{ml}$ of S.C. media containing $3 \mathrm{mg} / \mathrm{ml}$ methionine. At time points of 0,3 , and 10 min of chase, samples were centrifuged, supernatants were removed, and the cell pellets frozen on dry ice. Cells were lysed by glass-bead disruption and RNA was extracted using Qiagen RNeasy columns. RNA was eluted with water and $25 \mathrm{nCi}$ of each sample was loaded onto $1.2 \%$ agaroseformaldehyde gels. RNA was transferred to Hybond- $\mathrm{N}^{+}$membranes (Amersham) by vacuum blotting (Pharmacia-Biotech), UV-cross-linked, and sprayed with $\mathrm{En}^{3}$ hance (NEN). Blots were exposed to film with an intensifying screen for 4 days at $-80^{\circ} \mathrm{C}$.

\section{Separation of ribosomal subunits}

PSY580 and prp20-1 strains were grown a density of $1 \times 10^{7}$ $2 \times 10^{7}$ cells $/ \mathrm{ml}$ in met $^{-}$media. $5 \times 10^{8}$ cells were resuspended in a volume of $1 \mathrm{ml}$ of met $^{-}$media and incubated at $37^{\circ} \mathrm{C}$ for 10 $\mathrm{min}$. Cells were centrifuged briefly, resuspended in $1 \mathrm{ml}$ of fresh met $^{-}$media prewarmed to $37^{\circ} \mathrm{C}$, and labeled with $0.25 \mathrm{mCi}$ of [methyl- $\left.{ }^{3} \mathrm{H}\right]$ methionine for $10 \mathrm{~min}$ at $37^{\circ} \mathrm{C}$. Cells were collected, washed with $1 \mathrm{ml}$ of ice-cold water, and frozen on dry ice. Cells were resuspended in buffer B [50 mM Tris ( $\mathrm{pH} 7.5$ ), 50 mм NaCl, 1 mм DTT; Foiani et al. 1991] with protease inhibitors (Sigma) and 200 units of RNase inhibitor (Roche). Whole cell lysates were prepared by glass-bead disruption and lysates were microfuged for $5 \mathrm{~min}$ at $4^{\circ} \mathrm{C}$. Lysate $\left(20 A_{260}\right.$ units) was loaded onto $10-\mathrm{ml} 7 \%-25 \%$ linear sucrose gradients prepared in buffer B. Samples were centrifuged for $2.5 \mathrm{hr}$ at 39,000 rpm at $4^{\circ} \mathrm{C}$ in a Beckman SW-41 rotor. The gradients were fractionated and monitored continuously for $A_{254}$. Peaks corresponding to $60 \mathrm{~S}, 40 \mathrm{~S}$, and soluble fractions were collected in a volume of 0.5 $\mathrm{ml}$ and RNA was purified using RNeasy columns (Qiagen). Twelve nanoCuries of the $60 \mathrm{~S}$ and $40 \mathrm{~S}$ fractions were run on $1.2 \%$ agarose-formaldehyde gels.

\section{Acknowledgments}

We thank all of the investigators who generously shared yeast strains and plasmids. We thank M. Damelin and H. Morehouse for providing unpublished strains and D. Kressler for providing rRNA processing protocols. Thanks go to A. Brodsky, P. Ferrigno, A. McBride, T.S. Zimmerman, and E. Lei for critical reading of this manuscript. We thank P. Ferrigno for outstanding assistance and support with the DeltaVision microscope. This work was funded by grants from the National Institutes of Health (NIH) to P.A.S. and an NIH training grant to the DanaFarber Cancer Institute.

The publication costs of this article were defrayed in part by payment of page charges. This article must therefore be hereby marked 'advertisement' in accordance with 18 USC section 1734 solely to indicate this fact.

\section{References}

Adam, E.J. and S.A. Adam. 1994. Identification of cytosolic factors required for nuclear location sequence-mediated binding to the nuclear envelope. J. Cell Biol. 125: 547-555.

Adams, A., D.E. Gottschling, C.A. Kaiser, and T. Stearns. 1997. Methods in yeast genetics. Cold Spring Harbor Laboratory Press, Cold Spring Harbor, NY.

Aebi, M., M.W. Clark, U. Vijayraghavan, and J. Abelson. 1990. A yeast mutant, PRP20, altered in mRNA metabolism and maintenance of the nuclear structure, is defective in a gene homologous to the human gene RCC1 which is involved in the control of chromosome condensation. Mol. \& Gen. Genet. 224: 72-80.

Agard, D.A., Y. Hiraoka, P. Shaw, and J.W. Sedat. 1989. Fluorescence microscopy in three dimensions. Methods Cell Biol. 30: 353-377.

Aitchison, J.D., M.P. Rout, M. Marelli, G. Blobel, and R.W. Wozniak. 1995. Two novel related yeast nucleoporins Nup170p and Nup157p: Complementation with the vertebrate homologue Nup155p and functional interactions with the yeast nuclear pore-membrane protein Pom152p. I. Cell Biol. 131: 1133-1148.

Aitchison, J.D., G. Blobel, and M.P. Rout. 1996. Kap104p: A karyopherin involved in the nuclear transport of messenger RNA binding proteins. Science 274: 624-627.

Amberg, D.C., A.L. Goldstein, and C.N. Cole. 1992. Isolation and characterization of RAT1: An essential gene of Saccharomyces cerevisiae required for the efficient nucleocytoplasmic trafficking of mRNA. Genes \& Dev. 6: 1173-1189.

Amberg, D.C., M. Fleischmann, I. Stagljar, C.N. Cole, and M. Aebi. 1993. Nuclear PRP20 protein is required for mRNA export. EMBO J. 12: 233-241. 
Bataillé, N., T. Helser, and H.M. Fried. 1990. Cytoplasmic transport of ribosomal subunits microinjected into the Xenopus laevis oocyte nucleus: A generalized, facilitated process. $J$. Cell Biol. 111: 1571-1582.

Belgareh, N., C. Snay-Hodge, F. Pasteau, S. Dagher, C.N. Cole, and V. Doye. 1998. Functional characterization of a Nup159p-containing nuclear pore subcomplex. Mol. Biol. Cell 9: 3475-3492.

Bossie, M.A., C. DeHoratius, G. Barcelo, and P. Silver. 1992. A mutant nuclear protein with similarity to RNA binding proteins interferes with nuclear import in yeast. Mol. Biol. Cell 3: 875-893.

Cheng, Y., J.E. Dahlberg, and E. Lund. 1995. Diverse effects of the guanine nucleotide exchange factor RCC1 on RNA transport. Science 267: 1807-1810.

Corbett, A.H., D.M. Koepp, G. Schlenstedt, M.S. Lee, A.K. Hopper, and P.A. Silver. 1995. Rnalp, a Ran/TC4 GTPase activating protein, is required for nuclear import. J. Cell Biol. 130: $1017-1026$

Davis, L.I. 1995. The nuclear pore complex. Annu. Rev. Biochem. 64: 865-896.

DeHoratius, C. and P.A. Silver. 1996. Nuclear transport defects and nuclear envelope alterations are associated with mutation of the Saccharomyces cerevisiae NPL4 gene. Mol. Biol. Cell 7: 1835-1855.

de la Cruz, J., D. Kressler, D. Tollervey, and P. Linder. 1998. Doblp (Mtr4p) is a putative ATP-dependent RNA helicase required for the $3^{\prime}$ end formation of 5.8S rRNA in Saccharomyces cerevisiae. EMBO J. 17: 1128-1140.

Dykstra, C.C., K. Kitada, A.B. Clark, R.K. Hamatake, and A. Sugino. 1991. Cloning and characterization of DST2, the gene for DNA strand transfer protein beta from Saccharomyces cerevisiae. Mol. Cell. Biol. 11: 2583-2592.

Fabre, E. and E. Hurt. 1997. Yeast genetics to dissect the nuclear pore complex and nucleocytoplasmic trafficking. Annu. Rev. Genet. 31: 277-313.

Feng, W., A.L. Benko, J.H. Lee, D.R. Stanford, and A.K. Hopper. 1999. Antagonistic effects of NES and NLS motifs determine S. cerevisiae Rnalp subcellular distribution. I. Cell Sci. 112: 339-347.

Ferrigno, P. and P. Silver. 1999. Analysis of nuclear transport in vivo. Methods Cell. Biol. 5: 107-122.

Ferrigno, P., F. Posas, D. Koepp, H. Saito, and P.A. Silver. 1998 Regulated nucleo/cytoplasmic exchange of HOG1 MAPK requires the importin beta homologs NMD5 and XPO1. EMBO J. 17: 5606-5614.

Fischer, U., J. Huber, W.C. Boelens, I.W. Mattaj, and R. Luhrmann. 1995. The HIV-1 Rev activation domain is a nuclear export signal that accesses an export pathway used by specific cellular RNAs. Cell 82: 475-483.

Foiani, M., A.M. Cigan, C.J. Paddon, S. Harashima, and A.G. Hinnebusch. 1991. GCD2, a translational repressor of the GCN4 gene, has a general function in the initiation of protein synthesis in Saccharomyces cerevisiae. Mol. Cell. Biol. 11: 3203-3216.

Fornerod, M., M. Ohno, M. Yoshida, and I.W. Mattaj. 1997. CRM1 is an export receptor for leucine-rich nuclear export signals. Cell 90: 1051-1060.

Forrester, W., F. Stutz, M. Rosbash, and M. Wickens. 1992. Defects in mRNA $3^{\prime}$-end formation, transcription initiation, and mRNA transport associated with the yeast mutation prp20: possible coupling of mRNA processing and chromatin structure. Genes \& Dev. 6: 1914-1926.

Giese, G. and F. Wunderlich. 1983. In vitro ribosomal ribonucleoprotein transport. Temperature-induced 'graded unlocking' of nuclei. J. Biol. Chem. 258: 131-135.
Gorenstein, C. and J.R. Warner. 1977. Synthesis and turnover of ribosomal proteins in the absence of 60S subunit assembly in Saccharomyces cerevisiae. Mol. \& Gen. Genet. 157: 327332.

Görlich, D. 1998. Transport into and out of the cell nucleus. EMBO I. 17: 2721-2727.

Görlich, D., F. Vogel, A.D. Mills, E. Hartmann, and R.A. Laskey. 1995. Distinct functions for the two importin subunits in nuclear protein import. Nature 377: 246-248.

Görlich, D., N. Panté, U. Kutay, U. Aebi, and F.R. Bischoff. 1996. Identification of different roles for RanGDP and RanGTP in nuclear protein import. EMBO J. 15: 5584-5594.

Gorsch, L.C., T.C. Dockendorff, and C.N. Cole. 1995. A conditional allele of the novel repeat-containing yeast nucleoporin RAT7/NUP159 causes both rapid cessation of mRNA export and reversible clustering of nuclear pore complexes. J. Cell Biol. 129: 939-955.

Grandi, P., S. Emig, C. Weise, F. Hucho, T. Pohl, and E.C. Hurt. 1995. A novel nuclear pore protein Nup82p which specifically binds to a fraction of Nsp1p. J. Cell Biol. 130: 1263 1273.

Hartwell, L.H. 1967. Macromolecule synthesis in temperaturesensitive mutants of yeast. J. Bacteriol. 93: 1662-1670.

Heath, C.V., C.S. Copeland, D.C. Amberg, V. Del Priore, M. Snyder, and C.N. Cole. 1995. Nuclear pore complex clustering and nuclear accumulation of poly(A)+ RNA associated with mutation of the Saccharomyces cerevisiae RAT2/ NUP120 gene. J. Cell Biol. 131: 1677-1697.

Hellmuth, K., D.M. Lau, F.R. Bischoff, M. Kunzler, E. Hurt, and G. Simos. 1998. Yeast Los1p has properties of an exportinlike nucleocytoplasmic transport factor for tRNA. Mol. Cell. Biol. 18: 6374-6386.

Henry, M.F. and P.A. Silver. 1996. A novel methyltransferase (Hmtlp) modifies poly(A)+-RNA-binding proteins. Mol. Cell Biol. 16: 3668-3678.

Henry, M., C.Z. Borland, M. Bossie, and P.A. Silver. 1996. Potential RNA binding proteins in Saccharomyces cerevisiae identified as suppressors of temperature-sensitive mutations in NPL3. Genetics 142: 103-115.

Hood, J.K. and P.A. Silver. 1998. Cse1p is required for export of Srplp/importin-alpha from the nucleus in Saccharomyces cerevisiae. J. Biol. Chem. 273: 35142-35146.

Hopper, A.K., L.D. Schultz, and R.A. Shapiro. 1980. Processing of intervening sequences: A new yeast mutant which fails to excise intervening sequences from precursor tRNAs. Cell 19: $741-751$.

Hsu, C.L. and A. Stevens. 1993. Yeast cells lacking 5' $\rightarrow$ 3' exoribonuclease 1 contain mRNA species that are poly(A) deficient and partially lack the 5' cap structure. Mol. Cell. Biol. 13: 4826-4835.

Hurt, D.J., S.S. Wang, Y.H. Lin, and A.K. Hopper. 1987. Cloning and characterization of LOS1, a Saccharomyces cerevisiae gene that affects tRNA splicing. Mol. Cell. Biol. 7: 12081216.

Hurt, E., S. Hannus, B. Schmelzl, D. Lau, D. Tollervey, and G. Simos. 1999. A novel in vivo assay reveals inhibition of ribosomal nuclear export in Ran-cycle and nucleoporin mutants. J. Cell Biol. 144: 389-401.

Hurwitz, M.E. and G. Blobel. 1995. NUP82 is an essential yeast nucleoporin required for poly(A)+ RNA export. J. Cell Biol. 130: $1275-1281$.

Hurwitz, M.E., C. Strambio-de-Castillia, and G. Blobel. 1998. Two yeast nuclear pore complex proteins involved in mRNA export form a cytoplasmically oriented subcomplex. Proc. Natl. Acad. Sci. 95: 11241-11245.

Interthal, H., C. Bellocq, J. Bahler, V.I. Bashkirov, S. Edelstein, 
and W.D. Heyer. 1995. A role of Sep1 (=Kem1, Xrn1) as a microtubule-associated protein in Saccharomyces cerevisiae. EMBO J. 14: 1057-1066.

Izaurralde, E., U. Kutay, C. von Kobbe, I.W. Mattaj, and D. Görlich. 1997. The asymmetric distribution of the constituents of the Ran system is essential for transport into and out of the nucleus. EMBO J. 16: 6535-6547.

Jäkel, S. and D. Görlich. 1998. Importin beta, transportin, RanBP5 and RanBP7 mediate nuclear import of ribosomal proteins in mammalian cells. EMBO J. 17: 4491-4502.

Kadowaki, T., S. Chen, M. Hitomi, E. Jacobs, C. Kumagai, S. Liang, R. Schneiter, D. Singleton, J. Wisniewska, and A.M. Tartakoff. 1994. Isolation and characterization of Saccharomyces cerevisiae mRNA transport-defective (mtr) mutants. J. Cell Biol. 126: 649-659.

Kaffman, A., N.M. Rank, E.M. O'Neill, L.S. Huang, and E.K. O'Shea. 1998. The receptor Msn5 exports the phosphorylated transcription factor Pho4 out of the nucleus. Nature 396: $482-486$.

Khanna-Gupta, A. and V.C. Ware. 1989. Nucleocytoplasmic transport of ribosomes in a eukaryotic system: Is there a facilitated transport process? Proc. Natl. Acad. Sci. 86: $1791-1795$.

Koepp, D.M., D.H. Wong, A.H. Corbett, and P.A. Silver. 1996. Dynamic localization of the nuclear import receptor and its interactions with transport factors. J. Cell Biol. 133: 11631176.

Kondo, K., L.R. Kowalski, and M. Inouye. 1992. Cold shock induction of yeast NSR1 protein and its role in pre-rRNA processing. J. Biol. Chem. 267: 16259-16265.

Kressler, D., J. de la Cruz, M. Rojo, and P. Linder. 1997. Fallp is an essential DEAD-box protein involved in 40S-ribosomalsubunit biogenesis in Saccharomyces cerevisiae. Mol. Cell. Biol. 17: 7283-7294.

Kutay, U., F.R. Bischoff, S. Kostka, R. Kraft, and D. Görlich. 1997. Export of importin alpha from the nucleus is mediated by a specific nuclear transport factor. Cell 90: 1061-1071.

Larimer, F.W. and A. Stevens. 1990. Disruption of the gene XRN1, coding for a 5' $\rightarrow$ 3' exoribonuclease, restricts yeast cell growth. Gene 95: 85-90.

Lee, M.S., M. Henry, and P.A. Silver. 1996. A protein that shuttles between the nucleus and the cytoplasm is an important mediator of RNA export. Genes \& Dev. 10: 12331246.

Li, O., C.V. Heath, D.C. Amberg, T.C. Dockendorff, C.S. Copeland, M. Snyder, and C.N. Cole. 1995. Mutation or deletion of the Saccharomyces cerevisiae RAT3/NUP133 gene causes temperature-dependent nuclear accumulation of poly(A)+ RNA and constitutive clustering of nuclear pore complexes. Mol. Biol. Cell 6: 401-417.

Liang, S., M. Hitomi, Y.H. Hu, Y. Liu, and A.M. Tartakoff. 1996. A DEAD-box-family protein is required for nucleocytoplasmic transport of yeast mRNA. Mol. Cell. Biol. 16: 51395146.

Liu, Z., A. Lee, and W. Gilbert. 1995. Gene disruption of a G4DNA-dependent nuclease in yeast leads to cellular senescence and telomere shortening. Proc. Natl. Acad. Sci. 92: 6002-6006.

Loeb, J.D., L.I. Davis, and G.R. Fink. 1993. NUP2, a novel yeast nucleoporin, has functional overlap with other proteins of the nuclear pore complex. Mol. Biol. Cell 4: 209-222.

Moore, M.S. and G. Blobel. 1994. Purification of a Ran-interacting protein that is required for protein import into the nucleus. Proc. Natl. Acad. Sci. 91: 10212-10216.

Moritz, M., A.G. Paulovich, Y.F. Tsay, and J.L. Woolford Jr. 1990. Depletion of yeast ribosomal proteins L16 or rp59 dis- rupts ribosome assembly. J. Cell. Biol. 111: 2261-2274.

Murphy, R., J.L. Watkins, and S.R. Wente. 1996. GLE2, a Saccharomyces cerevisiae homologue of the Schizosaccharomyces pombe export factor RAE1, is required for nuclear pore complex structure and function. Mol. Biol. Cell 7: 1921-1937.

Murphy, R. and S.R. Wente. 1996. An RNA-export mediator with an essential nuclear export signal. Nature 383: 357360.

Nehrbass, U., H. Kern, A. Mutvei, H. Horstmann, B. Marshallsay, and E.C. Hurt. 1990. NSP1: A yeast nuclear envelope protein localized at the nuclear pores exerts its essential function by its carboxy-terminal domain. Cell 61: 979-989.

Nonet, M., C. Scafe, J. Sexton, and R. Young. 1987. Eucaryotic RNA polymerase conditional mutant that rapidly ceases mRNA synthesis. Mol. Cell. Biol. 7: 1602-1611.

Otaka, E. and K. Kobata. 1978. Yeast ribosomal proteins. I. Characterization of cytoplasmic ribosomal proteins by twodimensional gel electrophoresis. Mol. \& Gen. Genet. 162: 259-268.

Pemberton, L.F., J.S. Rosenblum, and G. Blobel. 1997. A distinct and parallel pathway for the nuclear import of an mRNAbinding protein. J. Cell Biol. 139: 1645-1653.

Petersen, N.S. and D.P. Nierlich. 1978. Yeast mutant, rna 1, affects the entry into polysomes of ribosomal RNA as well as messenger RNA. Mol. \& Gen. Genet. 162: 319-322.

Pokrywka, N.J. and D.S. Goldfarb. 1995. Nuclear export pathways of tRNA and $40 \mathrm{~S}$ ribosomes include both common and specific intermediates. J. Biol. Chem. 270: 3619-3624.

Powers, T. and P. Walter. 1999. Regulation of ribosome biogenesis by the rapamycin-sensitive TOR-signaling pathway in Saccharomyces cerevisiae. Mol. Biol. Cell 10: 987-1000.

Ripmaster, T.L., G.P. Vaughn, and J.L. Woolford Jr. 1993. DRS1 to DRS7, novel genes required for ribosome assembly and function in Saccharomyces cerevisiae. Mol. Cell. Biol. 13: 7901-7912.

Rosenblum, J.S., L.F. Pemberton, and G. Blobel. 1997. A nuclear import pathway for a protein involved in tRNA maturation. J. Cell Biol. 139: 1655-1661.

Rout, M.P., G. Blobel, and J.D. Aitchison. 1997. A distinct nuclear import pathway used by ribosomal proteins. Cell 89: $715-725$

Saavedra, C.A., C.M. Hammell, C.V. Heath, and C.N. Cole. 1997. Yeast heat shock mRNAs are exported through a distinct pathway defined by Riplp. Genes \& Dev. 11: 28452856.

Santos-Rosa, H., H. Moreno, G. Simos, A. Segref, B. Fahrenkrog, N. Panté, and E. Hurt. 1998. Nuclear mRNA export requires complex formation between Mex67p and Mtr2p at the nuclear pores. Mol. Cell. Biol. 18: 6826-6838.

Sarkar, S. and A.K. Hopper. 1998. tRNA nuclear export in Saccharomyces cerevisiae: In situ hybridization analysis. Mol. Biol. Cell 9: 3041-3055.

Schlenstedt, G., C. Saavedra, J.D. Loeb, C.N. Cole, and P.A. Silver. 1995a. The GTP-bound form of the yeast Ran/TC4 homologue blocks nuclear protein import and appearance of poly(A)+ RNA in the cytoplasm. Proc. Natl. Acad. Sci. 92: $225-229$.

Schlenstedt, G., D.H. Wong, D.M. Koepp, and P.A. Silver. 1995b. Mutants in a yeast Ran binding protein are defective in nuclear transport. EMBO J. 14: 5367-5378.

Schlenstedt, G., E. Smirnova, R. Deane, J. Solsbacher, U. Kutay, D. Görlich, H. Ponstingl, and F.R. Bischoff. 1997. Yrb4p, a yeast ran-GTP-binding protein involved in import of ribosomal protein L25 into the nucleus. EMBO J. 16: 6237-6249.

Seedorf, M. and P.A. Silver. 1997. Importin/karyopherin protein 
family members required for mRNA export from the nucleus. Proc. Nat1. Acad. Sci. 94: 8590-8595.

Seedorf, M., M. Damelin, J. Kahana, T. Taura, and P.A. Silver. 1999. Interactions between a nuclear transporter and a subset of nuclear pore complex proteins depend on Ran GTPase. Mol. Cell. Biol. 19: 1547-1557.

Senger, B., G. Simos, F.R. Bischoff, A. Podtelejnikov, M. Mann, and E. Hurt. 1998. Mtr10p functions as a nuclear import receptor for the mRNA-binding protein Npl3p. EMBO I. 17: 2196-2207.

Siniossoglou, S., C. Wimmer, M. Rieger, V. Doye, H. Tekotte, C. Weise, S. Emig, A. Segref, and E.C. Hurt. 1996. A novel complex of nucleoporins, which includes Sec13p and a Sec13p homolog, is essential for normal nuclear pores. Cell 84: 265275.

Snay-Hodge, C.A., H.V. Colot, A.L. Goldstein, and C.N. Cole. 1998. Dbp5p/Rat8p is a yeast nuclear pore-associated DEAD-box protein essential for RNA export. EMBO $I$. 17: 2663-2676.

Stade, K., C.S. Ford, C. Guthrie, and K. Weis. 1997. Exportin 1 (Crmlp) is an essential nuclear export factor. Cell 90: 10411050.

Stevens, A., C.L. Hsu, K.R. Isham, and F.W. Larimer. 1991. Fragments of the internal transcribed spacer 1 of pre-rRNA accumulate in Saccharomyces cerevisiae lacking $5^{\prime} \rightarrow 3^{\prime}$ exoribonuclease 1. J. Bacteriol. 173: 7024-7028.

Tollervey, D., H. Lehtonen, M. Carmo-Fonseca, and E.C. Hurt. 1991. The small nucleolar RNP protein NOP1 (fibrillarin) is required for pre-rRNA processing in yeast. $E M B O J$. 10: $573-$ 583.

Tollervey, D., H. Lehtonen, R. Jansen, H. Kern, and E.C. Hurt. 1993. Temperature-sensitive mutations demonstrate roles for yeast fibrillarin in pre-rRNA processing, pre-rRNA methylation, and ribosome assembly. Cell 72: 443-457.

Tseng, S.S., P.L. Weaver, Y. Liu, M. Hitomi, A.M. Tartakoff, and T.H. Chang. 1998. Dbp5p, a cytosolic RNA helicase, is required for poly(A)+ RNA export. EMBO J. 17: 2651-2662.

Tushinski, R.J. and J.R. Warner. 1982. Ribosomal proteins are synthesized preferentially in cells commencing growth. $J$. Cell Physiol. 112: 128-135.

Udem, S.A. and J.R. Warner. 1973. The cytoplasmic maturation of a ribosomal precursor ribonucleic acid in yeast. J. Biol. Chem. 248: 1412-1416.

Venema, J. and D. Tollervey. 1995. Processing of pre-ribosomal RNA in Saccharomyces cerevisiae. Yeast 11: 1629-1650.

Verschoor, A., J.R. Warner, S. Srivastava, R.A. Grassucci, and J. Frank. 1998. Three-dimensional structure of the yeast ribosome. Nucleic Acids Res. 26: 655-661.

Warner, J.R. 1971. The assembly of ribosomes in yeast. J. Biol. Chem. 246: 447-454.

. 1989. Synthesis of ribosomes in Saccharomyces cerevisiae. Microbiol. Rev. 53: 256-271.

Wente, S.R., M.P. Rout, and G. Blobel. 1992. A new family of yeast nuclear pore complex proteins. J. Cell Biol. 119: 705723.

Winston, F., C. Dollard, and S.L. Ricupero-Hovasse. 1995. Construction of a set of convenient Saccharomyces cerevisiae strains that are isogenic to S288C. Yeast 11: 53-55.

Xiao, Z., J.T. McGrew, A.J. Schroeder, and M. Fitzgerald-Hayes. 1993. CSE1 and CSE2, two new genes required for accurate mitotic chromosome segregation in Saccharomyces cerevisiae. Mol. Cell. Biol. 13: 4691-4702.

Yano, R., M.L. Oakes, M.M. Tabb, and M. Nomura. 1994. Yeast Srplp has homology to armadillo/plakoglobin/beta-catenin and participates in apparently multiple nuclear functions including the maintenance of the nucleolar structure. Proc.
Nat1. Acad. Sci. 91: 6880-6884.

Zabel, U., V. Doye, H. Tekotte, R. Wepf, P. Grandi, and E.C. Hurt. 1996. Nic96p is required for nuclear pore formation and functionally interacts with a novel nucleoporin, Nup188p. J. Cell Biol. 133: 1141-1152. 


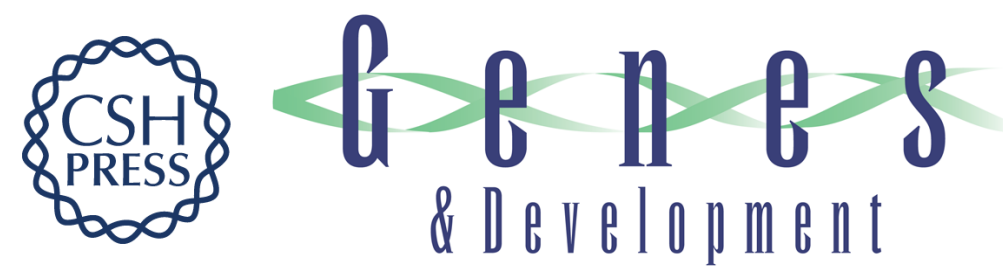

\section{Nuclear export of the small ribosomal subunit requires the Ran- GTPase cycle and certain nucleoporins}

Terence I. Moy and Pamela A. Silver

Genes Dev. 1999, 13:

References This article cites 99 articles, 70 of which can be accessed free at:

http://genesdev.cshlp.org/content/13/16/2118.full.html\#ref-list-1

License

Email Alerting Receive free email alerts when new articles cite this article - sign up in the box at the top Service right corner of the article or click here.

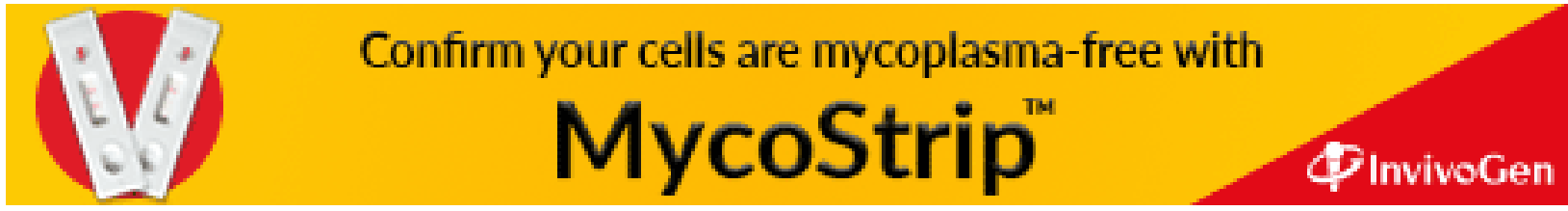

